\title{
OBLIQUE VIEWS AND THREE-DIMENSIONALITY IN MAYA ART
}

Michel Graulich Université Libre de Bruxelles

Schäfer's 1919 study on Egyptian art remains an extremely useful tool, not only for the egyptologist, but for all those interested in ways of representation with no perspective.

Introducing the English translation (1974), Gombrich does not hesitate to state: "It constitutes indeed the only attempt ever made of analyzing an artistic style as a mapping procedure". Schäfer, he goes on, teaches us the transformation-rules we have to apply to translate and to understand the Egyptian image.

Schäfer's fundamental thesis does not surprise any more. In their attempts to reproduce nature, the Egyptians construct their images summarizing those physical aspects of the object which they consider to be the essential, or more characteristic. To this effect, they rely on mental images rather than on an incomplete and truncated appearance. To represent a three-dimensional object on a flat surface, they proceed by "frontal views" of parts of the object: that which seen frontally en face or in profile extends into the third dimension is transferred to the flat plane of the image. Hence, the typical way of presenting man with shoulders and eyes en face; head, limbs, and torso in profile. Ideally, in such an image, "the at first sight confusing appearance of the parts on the two-dimensional plane can in fact be shown to conform to the simple technical rule, that in their two-dimensional projection, parts protruding from the three-dimensional plane must be seen in profile, and parts extending on the plane en face" (Iversen 1975:35).

This thesis is developed by Schäfer in a masterly manner, with countless examples in support. He does not flinch from any difficulty. He shows the ancient Egyptian's apparent lack of interest in depth, oblique views, non-frontal ones, foreshort- 
enings; a awkward distortions are systematically ignored, the illusion creating techniques rejected. Space is composed of successive flat surfaces, without depth. Even when oblique views seem to be represented, e.g. in the series of overlapping characters, one should visualize, according to Schäfer, groups looked at frontally but groups arranged in an extremely ordelry way.

Schäfer certainly goes too far sometimes. There are more foreshortenings in Egyptian art than he imagines (Iversen 1975 $11,37)$ but, true enough, they do not give the impression of being perspective. However, he does interest us most with regard to our purpose, when he asserts that the characteristics of the Egyptian image are also those of all "pre-Greek" arts, meaning, of all arts, whichever their epoch, that have not been influenced by ancient Greece. The techniques of creating illusion all go back to ancient Greece; it was in the 5th century B.C. that foreshortenings, shadowing, bird's eye views, perspective appeared there. Wherever artists made use of these techniques, they were tributary to the Greeks, who first admitted the fact that the aspect of an object changes according to its position, and who first found themselves bound by the way their subject stood before them, seen from a certain angle (Brunner-Traut 1974).

Gombrich mentions studies which have made gaps in this theory without, however, distroying it. Amongst the cited examples of "pre-Greek" arts having made use of illusion techniques are the Maya and, more specifically, the famous "foreshortened" vanquished character on the entry wall of Room 2 of Bonampak. It is for the experts in Maya art to decide whether that is exactly how things are, says Baines (1974:365).

The call has not been heard. Generally, it is considered that the pre-Colombian civilizations in general, including the Maya, did not know the oblique views and the illusion techniques. The purpose of this paper is to submit a certain number of indications which suggest, to the contrary, that at the height of their civilization, in the Late Classic (600-900 A.D.), immediately before their collapse, the Maya multiplied their investigations into the field of third dimension and that even, in certain places, they practically arrived at the same point as the Greeks at the end of the 6th century B.C. Rather than to demonstrate peremptorily, I would like to suggest useful research 
directions. Any demonstration is, nevertheless, more arduous in an art which, contrary to Egyptian art, is all sinuosity, curves, fluidity, free lineage, an art ignorant of the restraints of the graticule, systems of rigorous proportions, meticulous constructions.

To my knowledge, Grieder (1964) is the only one to have explored systematically, although briefly, the field of the third dimension in Maya art. He differentiates the problems of "form", i.e. of suggestion of the mass and the roundness of objects, and the problems of "space" or suggestion of a three-dimensional void on a flat surface. To show solid form, he explains, the Maya invented seven techniques: combined front and profile views, overlapping, foreshortening, "half-view", variations in the line weight, arbitrary shading, and detached contours; to suggest spatial depth they only used overlapping and raising the level.

As to the "form" or volume, let's bypass the first technique, which certainly is not one creating illusion. As for overlapping, Grieder mentions as an example, the arms, the clothes or ornaments which cover certain parts of the body. Such elements, however, mostly overlap each other necessarily and constantly in the figure represented, they are part of it and essential for it's identification. One can speak of illusion techniques only when the overlapping is the result of the personal standpoint of the spectator. As for the foreshortening, it is defined as a "technique to render the aspect of the objects and figures of which certain dimensions are foreshortened by the effect of geometrical perspective" (Principes d'analyse. .. 1978:696). As such, the technique is at the basis of oblique views and perspective. Grieder, however, uses it in a far broader sense, since he sees foreshortenings in a shoulder or a dwarf represented frontally or in profile. To be sure, he illustrates his point showing another dwarf, this time seen from three-quarter angle, i.e. obliquely, but he does not enlarge on the subject. Other authors, however, speak as regards the Maya of a "complex and well understood foreshortening system" (Gioseffi 1966:194). We will see that this really is the case.

Half-views consist in "cutting off part of the pattern or surface to indicate that the design continues on an invisible or receding surface". It is also what is done when one chooses to 
represent something en face or in profile: one necessarily sacrifices the other side. Often for that matter, to represent "in profile" an object whose most characteristic aspect is frontal, one merely cuts part of the frontal view. Nothing therein that is not "pre-Greek".

The weight of lines varied, Grieder points out, depending on whether general outlines or details within these forms were concerned. The difference can however be accounted for by the pre-eminence of the principal outline in the meso-american art, not by a wish to suggest volume. It is also this pre-eminence of the external contour that explains why it was made to stand out on figure painted in black, which would otherwise have seemed to have no contour at all. Nevertheless, it should be added that even the thickness of main contour seems to vary (e.g. Robicsek 1981:54-5, vases 59,60): a thorough scrutiny is necessary, taking into account the possibility of uncalled for retouches by modern "restorers".

Finally there is the arbitrary shading (or the shaping by shades). On a Tikal vase (Foncerrada de Molina and Lombardo de Ruiz 1979:228 -9) the lighter shade chosen for the sides of the torso or the arms of the main character as well as for the sides of a vessel can only be explained in my opinion by the wish to mark clearly that precisely they are the sides and this suggests volume. Such is the opinion, for that matter, of Michael Coe (1982), who gives other examples in support (cf. also Robicsek 1981:112 fig. 13,189 fig. $61=$ Coe 1978 No 12). But Tate (1983), sticking to the prevailing opinion, which classifies the Maya art amongst the arts qualified by Schäfer as "preGreek", makes reserves: "That the Mayas manipulated light or used chiaroscuro, even in reserve, would be a startling discovery about the Mayas' visual interpretation of their world-view". To her, the darker areas and mottlings within a contour could be the effect of painting techniques used: "it is possible that this mottling is due to an uneven loading and discharge of oxides from the brush".

More advanced technological studies could throw more light on this question, although Tate's assumption does not seem very likely. We will see that the attempts at showing volume were more numerous than is believed. It should also be brought to the reader's attention that the Egyptian paintings of the 19th 
dynasty (Schäfer 1974:72) bear witness of a similar phenomenon of variation in tone. As with the Maya, the selective distribution of the mottlings excludes an uncontrolled effect. Schäfer, of course, refuses to see in it a technique tending to render roundness: to him, the intention was to show the warmer tone that colours have in the shade. But the result of such attempts to take shadows into account is, in any case, that the figures acquire more body.

With regard to space, Grieder only mentions overlapping and raising the level but here again, there is more. On the whole, Grieder's point of view is traditional: he sets little value on foreshortenings, oblique views; he does not mention any research in the field of perspective, timid as that may be. To him, the Maya do not deviate from the canons of "non-perspective".

Like the ancient Egyptians, the Maya would probably not have hesitated to define art as "the reproduction of nature" (Schäfer 1974:46). No ancient text supports this assertion, but with the Aztecs, who, by our standards, have even less than the Maya succeeded to render the visually perceived, a good artist was expected to "reproduce what he sees, its reality and its appearance" (Seler 1902-23:2, 622:3; León-Portilla 1968: 165).

Maya art, for that matter, develops in the direction of reproducing reality with ever-increasing fidelity. Although, at first, they combine front and side-face views in the figures on the stelae, evern the first century of the Late Classic they had almost perfectly controlled the representation entirely en face or in profile and, having mastered this, they had started to tackle the study of the body in movement. From the beginning, however, they seem to have been shocked by the excessive and arbitrary oppositions in a same figure between the parts en face and in profile: they try to mediatise, to suggest that one is in the presence of a three-quarer view. The miniature Hauberg stela, dating back to the 2nd-3rd centuries, supplies an excellent example (Before Cortés 1970: № 169; Greene 1972: pll. 118). The ruler is shown in profile; shoulders en face, one hand en face, the other in profile. But at the time, the lower limbs were presented in profile, one behind the other, overlapping as little as possible. The small skirt that was of course to enfold both legs, consequently seems much too large for a side-face 
view. So, the hips are presented from a three-quarter angle by moving the flap decorating the centre of the loincloth to the left and thus narrowing one of the sides of the small skirt (fig. 1). The same phenomenon can be observed on stela 1 of Tikal (W. Coe 1967:92; Jones and Satterthwaite 1982: fig. 1, 83 a, b). Nonetheless, the fact remains that the three-quarter view is issued from partial frontal views.

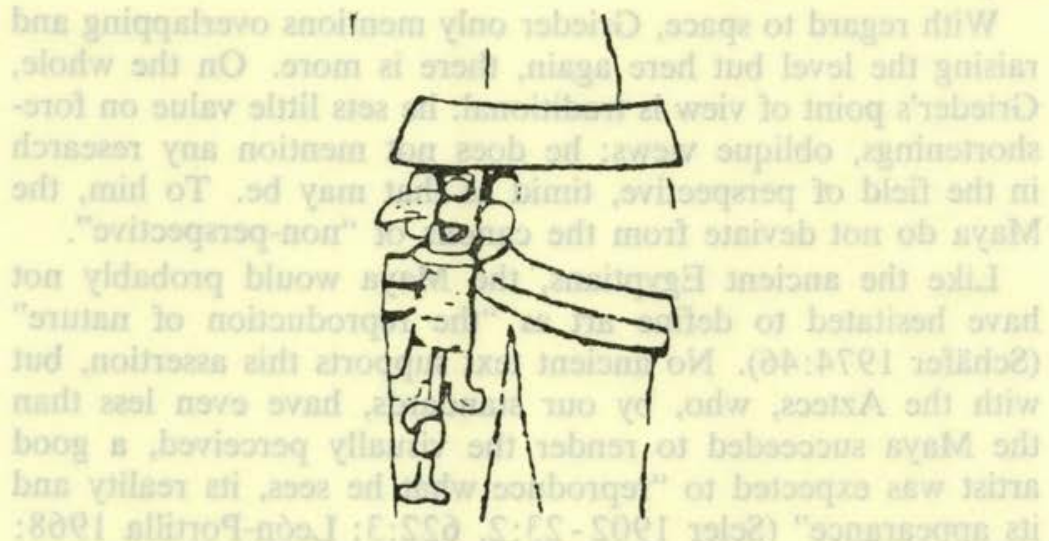

Figura 1. Hauberg stela, detail.

In the Late Classic, there is a literal outburst of research in every direction, to render volume and, to a smaller degree, space. Both the best and the worst proof comes from Copan, where the tendency to hollow out stone more and more deeply, until obtaining high-relief, even sculpture in the round, is well known. This obviously shows the concern to put volume in evidence but it is of course to the detriment of two-dimensionality. The same phenomenon occurs at Yaxchilan and at Piedras Negras, where they went as far as tlol perforate the relief (Before Cortés 1970: No 174; Morley 1953: pl. 70 a; Soustelle 1966: pl. 80 ).

The determination to render volume having been clearly established, let us explore the means which respect the flat surface. When a character is seen in profile, most of the time the hinder outline of the hidden leg is shown (not always: cf. the Brussels stela, M. and M. Graulich, No 4). This overlapping is not at all unavoidable and is, of course, not done with 


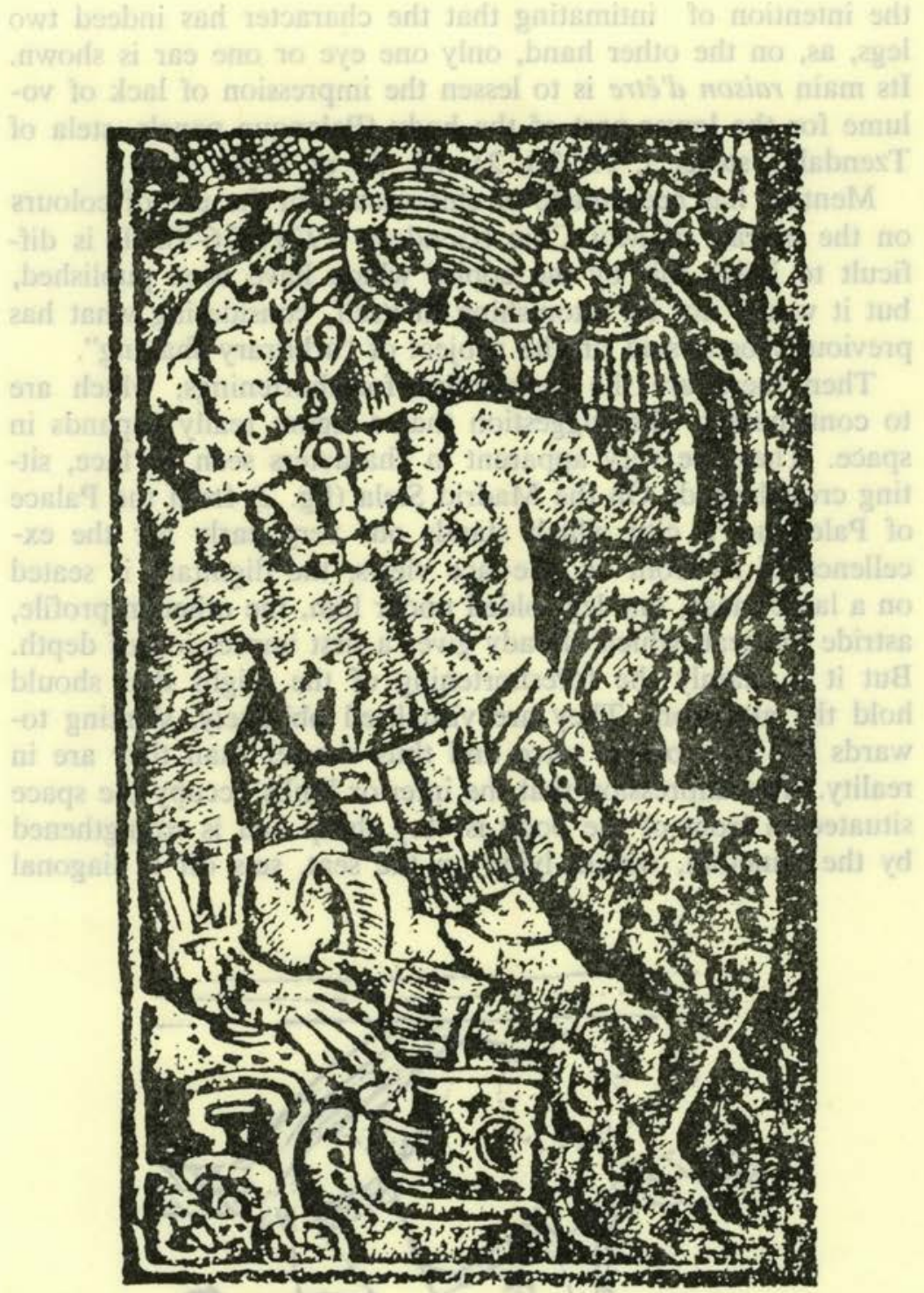

Figura 2. Madrid stela, Museo de América (S. Toscano, Arte precolombino de México y de la América Central, México City 1944, p. 251). 
the intention of intimating that the character has indeed two legs, as, on the other hand, only one eye or one ear is shown. Its main raison d'être is to lessen the impression of lack of volume for the lower part of the body (Palenque panels, stela of Tzendales, stelas $5,19,20,21,22,30$ of Tikal, etc.).

Mention has been made of chiaroscuro in the use of colours on the murals of Mul Chic (Gendrop 1971: 56-9). It is difficult to judge this by the copies which have been published, but it would not be astonishing in itself, considering what has previously been said on the subject of "arbitrary shading".

Then there are the perspective foreshortenings, which are to contribute to the suggestion that a figure really expands in space. They are very apparent in characters seen en face, sitting cross-legged. On the Madrid Stela (fig. 2) from the Palace of Palenque, a city which stands out very early for the excellence of its front or side-face views, the dignitary is seated on a large mask, one leg folded under him, the other in profile, astride the seat, which already gives a first impression of depth. But it is mainly the foreshortening of the thighs that should hold the attention. They are visualised obliquely, slanting towards the base of the torso and thus shorter than they are in reality. The impression that the inferior limbs occupy the space situated in front of the body is very sharp and is strengthened by the loincloth, which, lying on the seat, sets off a diagonal

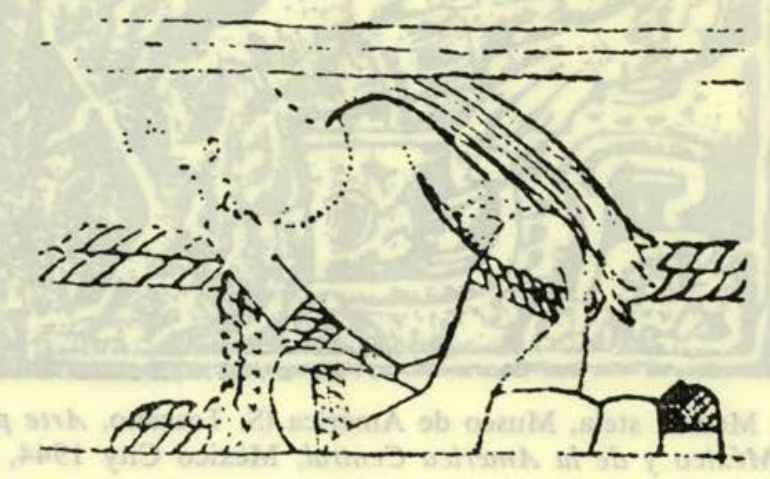

Figura 3. Altar 10, Tikal (after Jones and Satterthwaite fig. 35). 
flowing into a curve and hiding the right leg. Other foreshortenings on the lower limbs appear, for instance on a panel of Lacanhá, on stela 1 at Ixkún and on stela 3 at La Mar (Greene 1972: p. $11.77,165,24)$ and on altar 10 at Tikal (fig. 3). Regarding painting we should mention the captive in the "Trial of the Prisoners" scene at Bonampak (room 2, entrance wall, first prisoner, left upper part-fig. 4) and certain codex style vases (Robicsek 1981: 21 vase 18; 24 vase 111 , etc.).

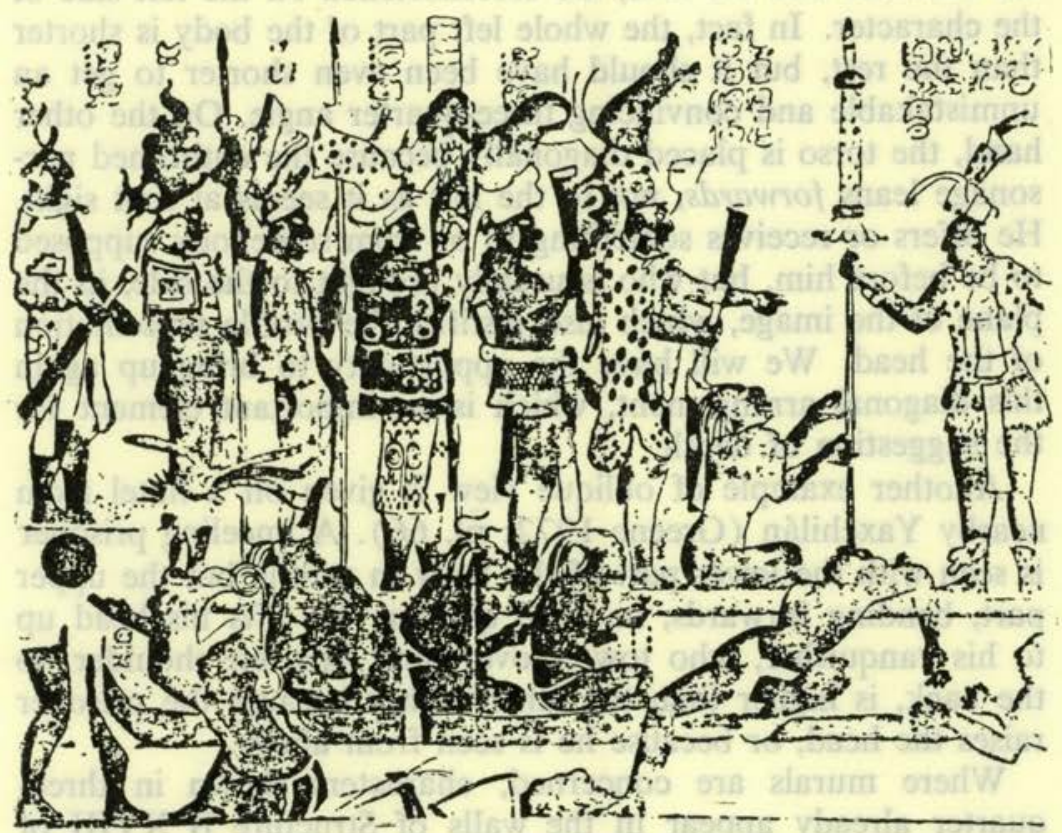

Figura 4. Battle scene and "arraignment of the prisoners", detail, Bonampak (after Ruppert, Thompson, Proskouriakoff).

Up to then, only the thighs were seen obliquely. But, not unlike the Greeks when they started on the way that would lead them to the perspective, the Maya also endeavoured to draw bodies almost entirely seen in oblique. Such three-quarter views imply, needless to say, a display in three dimensions, with part of the body on the foreground and the other part more in the background, therefore further back, meaning smaller, fore- 
shortened. It should be noted however that now and then there seems to be inverted "perspective", the part of the body more distant from the spectator being larger than the other. Nothing, as yet, is systematic or co-ordinated in this regard, in this period of experimenting that was the 8 th century.

On the Lacanhá panel mentioned before, the dignitary has the head in profile but, for the rest, he is pictured slightly in three-quarter. To make sure it suffices to establish how the loincloth is off-axis and how much the clothes enfolding the hips, the shoulder and the arm, are foreshortened on the left side of the character. In fact, the whole left part of the body is shorter than the rest, but it should have been even shorter to get an unmistakable and convincing three-quarter angle. On the other hand, the torso is placed diagonally because the enthroned personage leans forwards, not to the left as it seems at first sight. $\mathrm{He}$ offers or receives something to or from somebody supposed to be before him, but who is usually brought to the side, in the plane of the image, which also justifies the profile presentation of the head. We will have the opportunity to bring up again this diagonal arrangement, which is an important element for the suggestion of depth.

Another example of oblique view is given on a lintel from nearby Yaxchilán (Greene 1972: pl. 66). A kneeling prisoner is seen with the lower part of the body in profile but the upper part, bending forwards, in three quarter. He lifts his head up to his vanquisher, who towers over him. His left shoulder, to the back, is higher than the other, either because the prisoner raises the head, or because he is seen from above.

Where murals are concerned, characters shown in threequarter already appear in the walls of Structure B XVIII of Uaxactún (Morley 1953: pl. 50). But it is at Bonampak that a great number of them can be found. There is, for instance, the character at the extreme left of the main register of Room 1 (on the wall opposite the entrance), seen slightly in oblique and, especially the vanquished person lying at the feet of the ruler in the scene of the "Trial of the Prisoners" (Room 2, wall opposite entrance) (fig. 4). If he is placed diagonally, it is to suggest, not that he is bending forwards this time, but reclining to the back. Even certain characters who, at first glance, seem to be entirely en face, except for the head, have the shoulders 
slightly in a three-quarter angle, precisely to soften the transition towards the face in profile. There are also movements of rotation, not always successful. In certain cases, the joinings are a complete mess like in the seated character (Room 1, entrance wall, main register, 3 rd figure from the left), whose lower part, perfectly in profile, is turned to the right and the rest, nearly entirely in profile also, to the left. Among the most interesting figures on the other hand, should be mentioned those who, arranged in a file, seem to be leaning slightly to the side, and thus move out of the plane defined by the file, to see what is going on ahead of them (Room 1, right wall, 1st personage to the left; Room 3, right wall, 2nd character to the left) (fig. 5) or that other medallion figure whose elbow looks as if it is
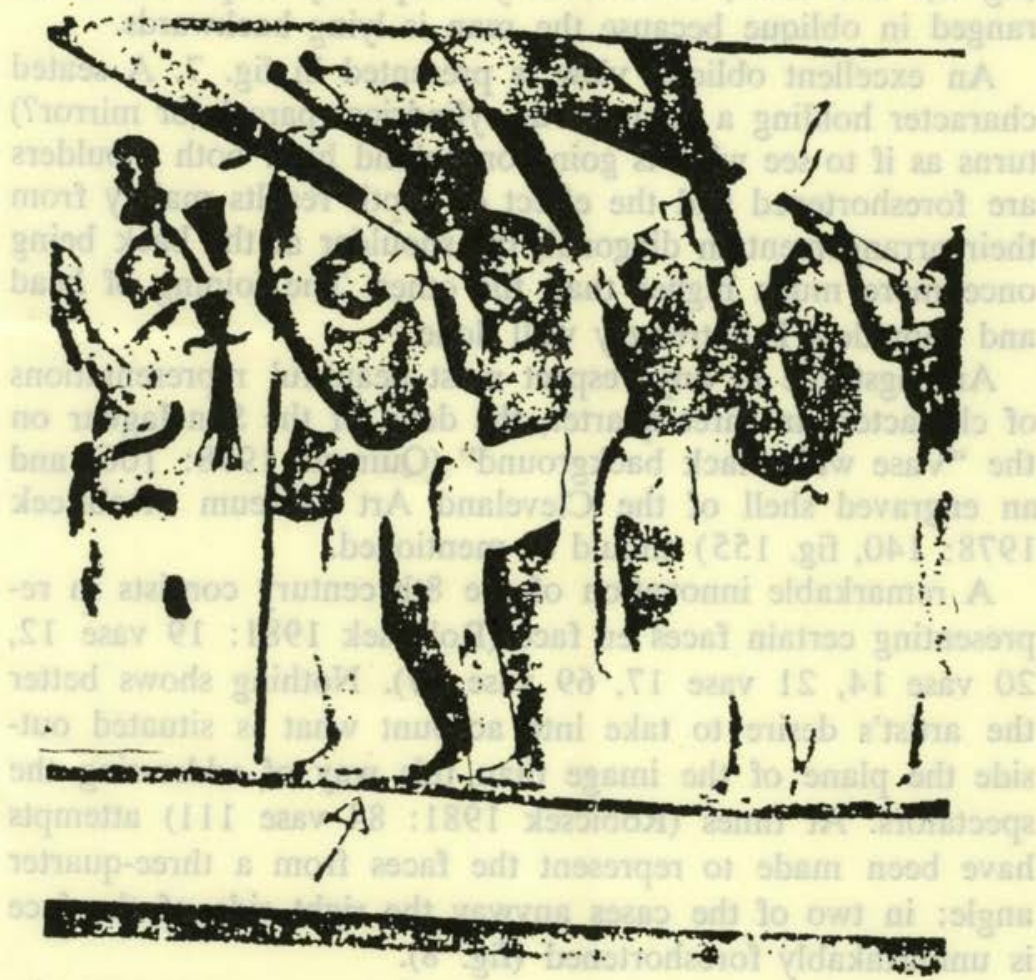

Figura 5. Musicians, Room 3, Bonampak (after Ruppert, Thompson, Proskouriakoff). 
pointing distinctly to the spectator (Room 2) (Ruppert, Thompson and Proskouriakoff 1955: copy of Tejada; Piraux 1983).

On the vases, the figures in three-quarter are plentiful, especially in the exceptional selection put together by Robicsek (1981). We discover first of all numerous animals pictured in a masterly way (p. 25 vases 30,$31 ; 26$ vase $33 ; 2 \overline{8}$ vases 39 , $40 ; 30$ vases 46,$47 ; 32$ vase 50 ). Seated or standing, they often execute a very convincing rotating movement. In one case (p. 33 vase 53 ) it is a bat, wings spread, seen in oblique. In another example (p. 170 vase 140 ) a deer in profile looks as if it has its tail turned towards the spectator. Next there are the men and women partially or entirely in three-quarter (p. 28 vase $40 ;$ p. 57 vase 68 , etc.). Vase 110 of Robicsek (1981: 84) presents a character lying on his back, legs folded (fig. 6). The torso, unfortunately completely in profile, is arranged in oblique because the man is lying backwards.

An excellent oblique view is presented in fig. 7. A seated character holding a voluminous cylindrical parcel (or mirror?) turns as if to see what is going on behind him: both shoulders are foreshortened and the effect of depth results mainly from their arrangement in diagonal, the shoulder at the back being once more much higher than the other. The joining of head and shoulders is extremely well done.

Amongst the in any respect most beautiful representations of characters in three-quarter, the deity of the Sun-Jaguar on the "Vase with black background" (Quirarte 1978: 106) and an engraved shell of the Cleveland Art Museum (Robiscek 1978: 140, fig. 155) should be mentioned.

A remarkable innovation of the 8 th century consists in representing certain faces en face (Robicsek 1981: 19 vase 12, 20 vase 14,21 vase 17,69 vase 87). Nothing shows better the artist's desire to take into account what is situated outside the plane of the image than this way of addressing the spectators. At times (Robicsek 1981: 84 vase 111) attempts have been made to represent the faces from a three-quarter angle: in two of the cases anyway the right side of the face is unmistakably foreshortened (fig. 8).

One of the more commonly used means to suggest the volume of the body consists in incurvating the belt of the skirt 


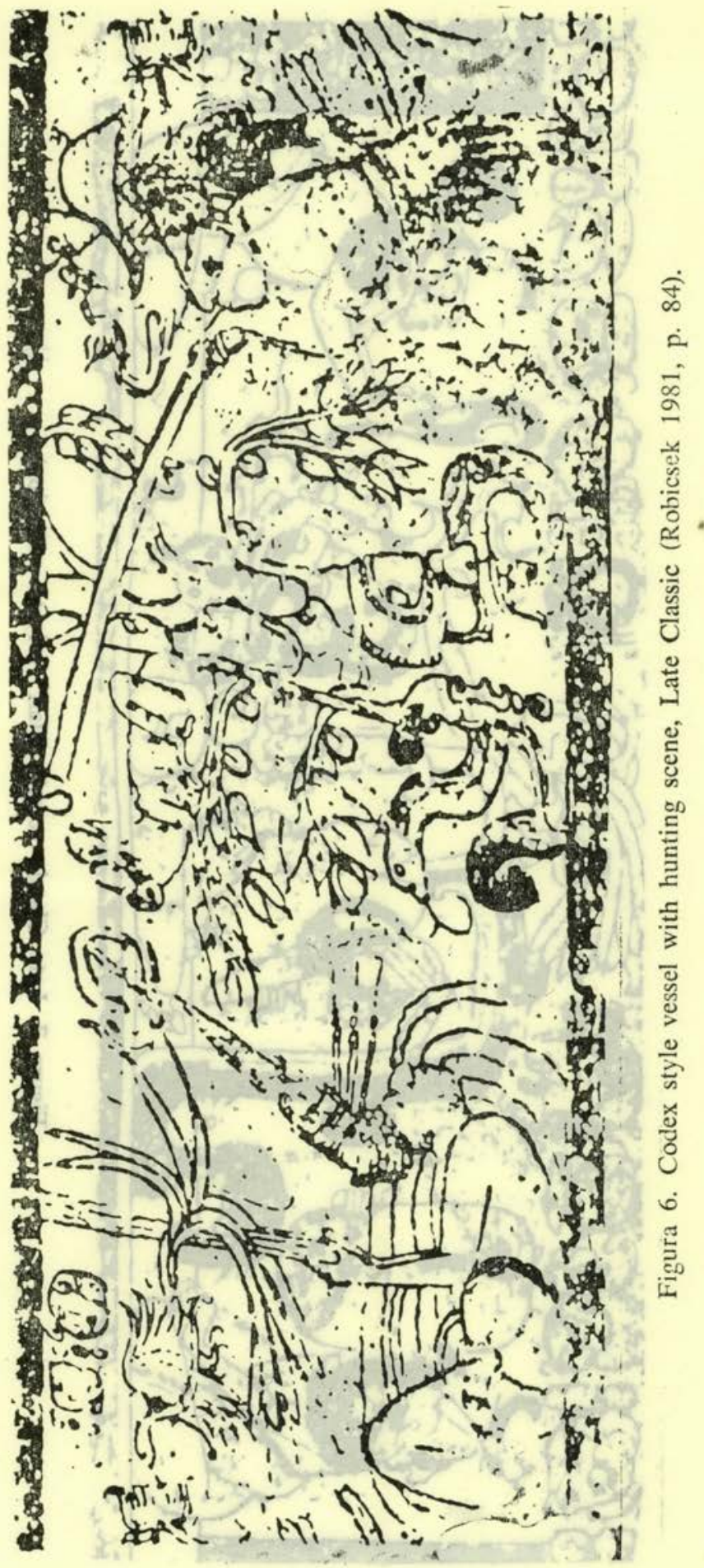




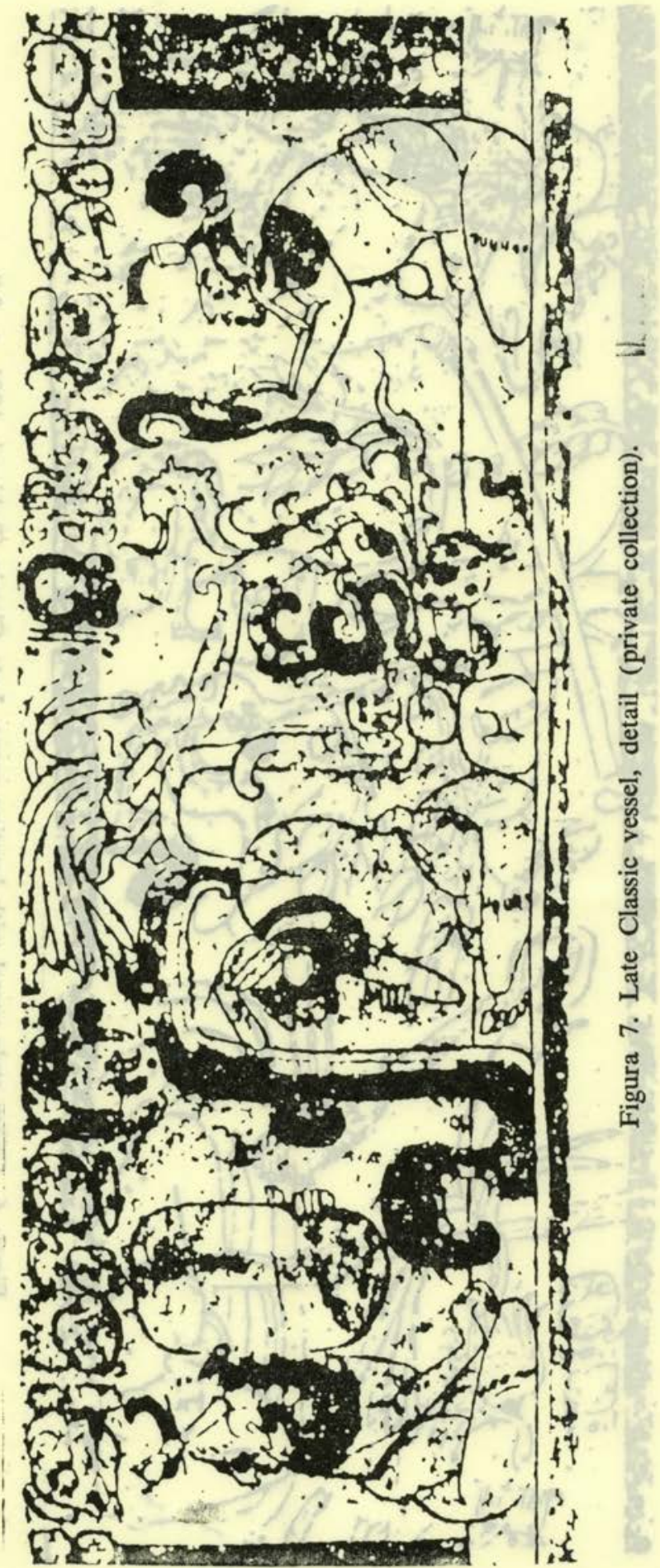




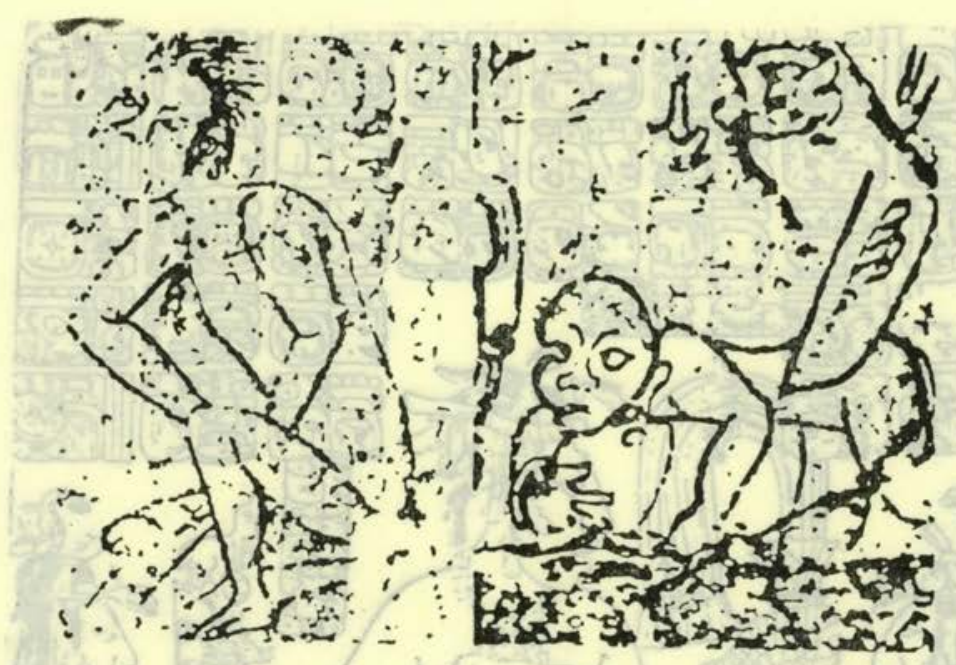

Figura 8. Faces in three-quarter view (Robicsek 1981, p. 84).

or of the loin-cloth. In the beginning, the belt was kept straight, which corresponded to the image one had in mind. Early in the Late Classic (Proskouriakoff 1950: 65) the distortion represented by the incurvation is spreading and its aim is certainly the rendering of volume. The deformation is indeed more accentuated depending on whether the character is fat or thin. On the Madrid stela for example (fig. 2) the dignitary is lank and the belt is slightly incurvated. The same goes for the panel of Temple XIV of Palenque (Greene 1972: pl. 10). On the panel of the slaves on the other hand, still in the same place, the ruler is plump and the deeply incurvated belt beautifully fits the roundness of the body (Greene 1972: pl. 38; Anton 1970: pl. 134) (fig. 9). In Piedras Negras the curve of the belt of a character in profile is distorted because of the oblique view (fig. 10).

Palenque also prides itself in an exceptional innovation, because it is one of the rare sites where pleats of the clothes are marked, so as to show the volume of the bodies (Panels of the Temple of the Cross, of the Slaves, stela of Madrid...). These pleats can also be found on certain vases in codex style 


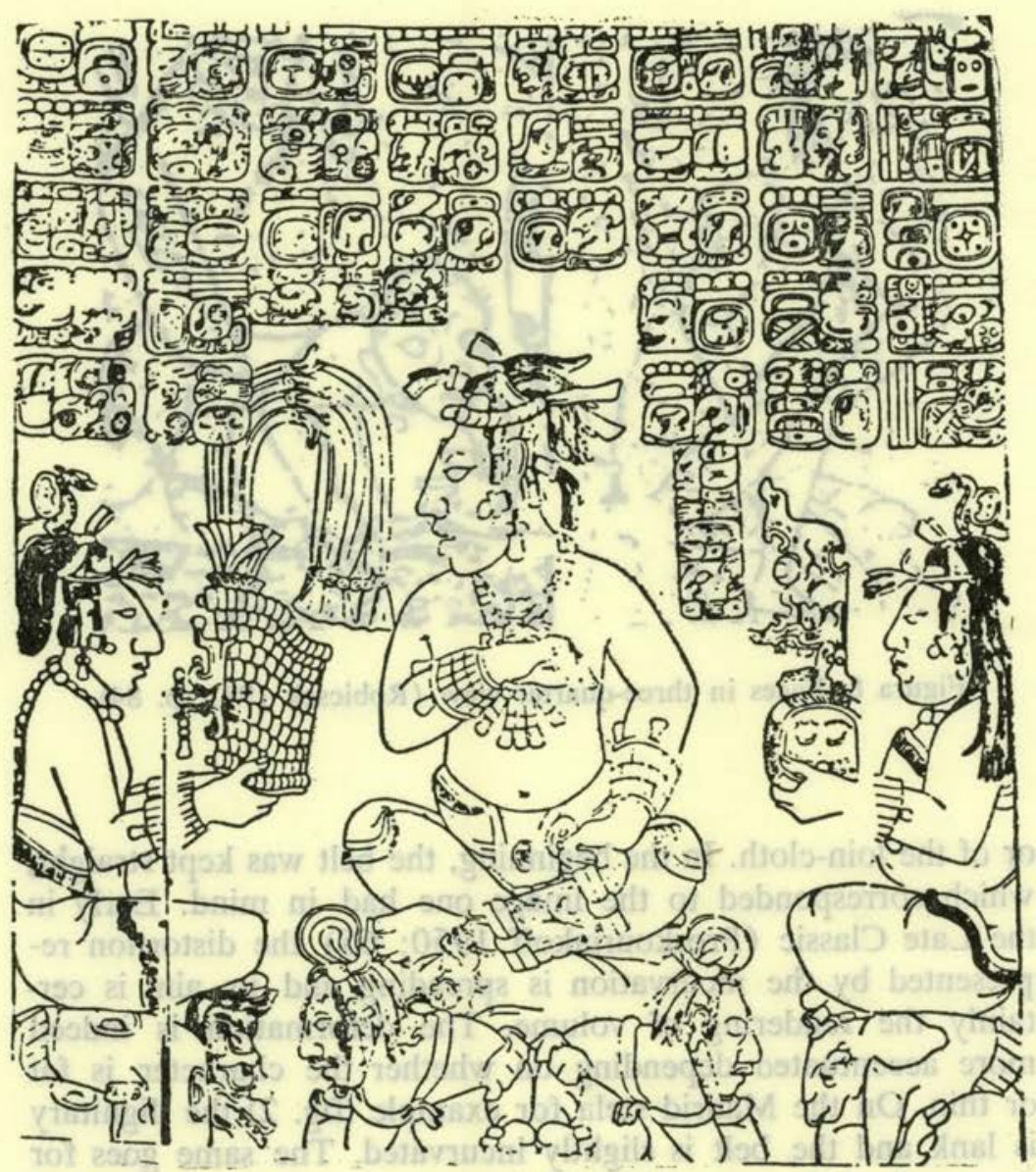

Figura 9. Tablet of the Slaves, Palenque (after M. Covarrubias, Indian Art of Mexico and Central America, New York 1957).

(Robicsek 1981: 50 vase 50, 67, vase 82 ). What's more, certain painters of vases also had the idea of indicating the folds or bulges of well-fed bellies, by curved lines rendering their thickness (Robicsek 1981: 20 vase 15, 54 vase 59).

The panel of the slaves in Palenque, already mentioned, has other remarkable characteristics. First of all, the oblique view on the ruler's right hand and the impression of depth it gives 


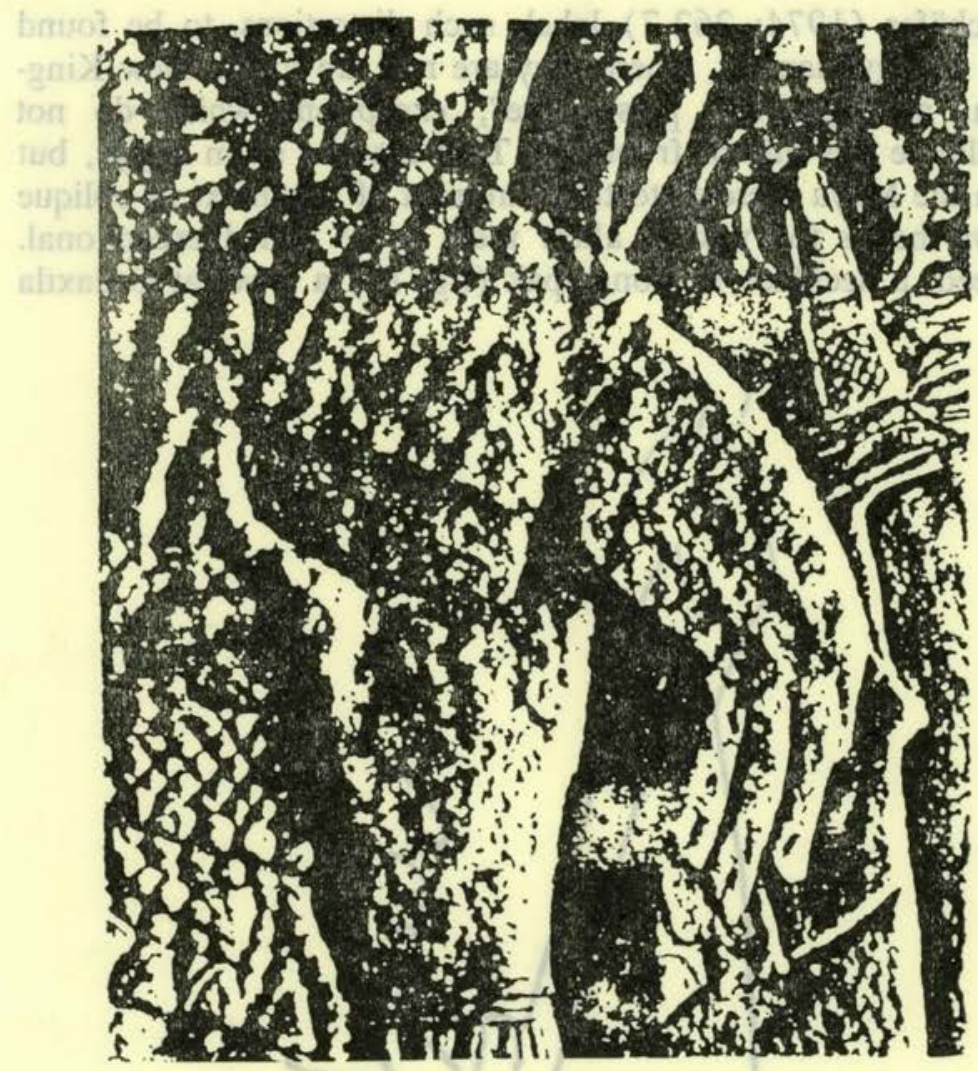

Figura 10. Detail of stela 10, Piedras Negras.

off are absolutely remarkable (compare with Robicsek 1981; 53 vase 56). Also, the ruler is adorned with large bracelets which in frontal view take on the shape of a trapezium (e. g. Panel of Temple XIV at Palenque; stela 3 of La Mar: Greene 1972 pl. 24; lintel 2 of Yaxchilán: Greene 1972: pl. 26; Proskouriakoff 1950: p. 11.79, 85). But here, these bracelets (fig. 9) are seen obliquely and their brims consequently incurvated, enhance the roundness of the arms. Similar incurvations, less sharp, can be seen on stela 1 at Chinikihá and on lintel 15 at Yaxchilán (Greene 1972: p. 11.14, 33) for instance. 
Schäfer (1974: 262-7) labels such distortions, to be found also in Egyptian art, where they are rare up to the New Kingdom, as "apparent perspective", exceptions which do not invalidate the rule of frontality. That may be so in Egypt, but with the Maya these distortions are part of a context of oblique views that is too vast to allow them to be called exceptional. Indeed, a necklace at Bonampak (fig. 11) a jewel at Cacaxtla

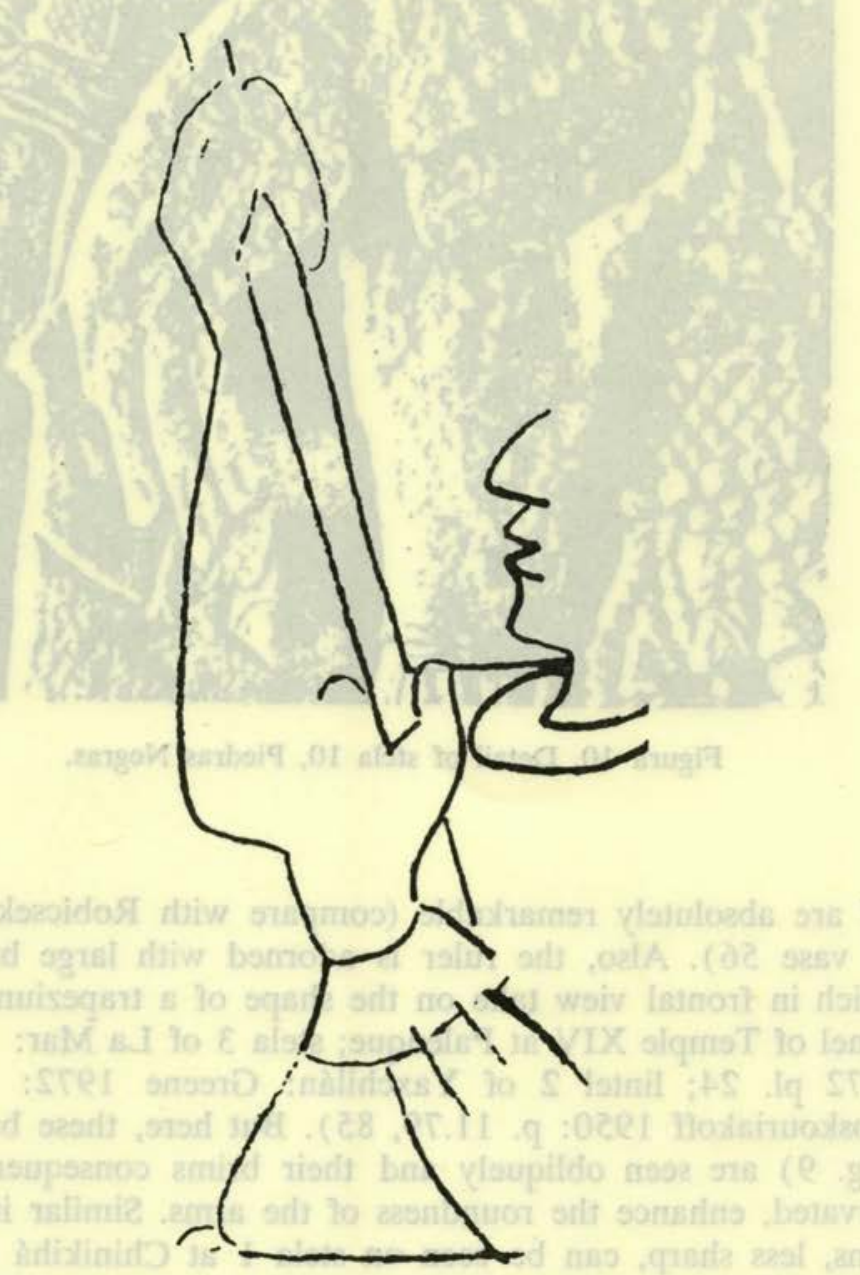

Figura 11. Detail of fan bearer, Room 1, Bonampak. 


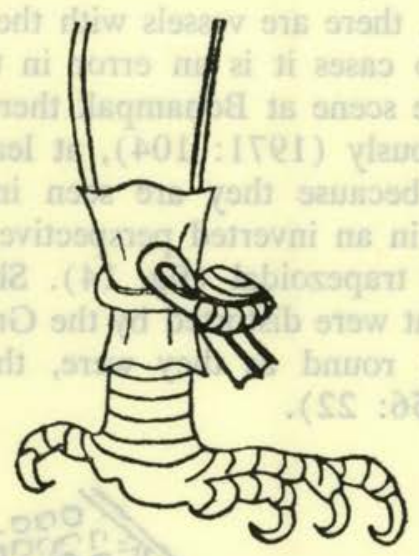

Figura 12. Detail of ruler desguised as an eagle, Structure A, Cacaxtla.

(fig. 12) are also treated with very meaningful perspective foreshortenings. At Bonampak, in the scene of the musicians (Room 1), the extremities of the huge wooden trumpets are clearly rounded (fig. 13), while they are straight in the battle scene (Room 2). On certain vases not only trumpets, but also vessels with rounded extremities can be found (M. Coe 1973: 72-3, 104-5; Robicsek 1981: 21 vase 17; on a famous vase of Nebaj also: Morley 1953: pl. 89 a, and at Bonampak, on the

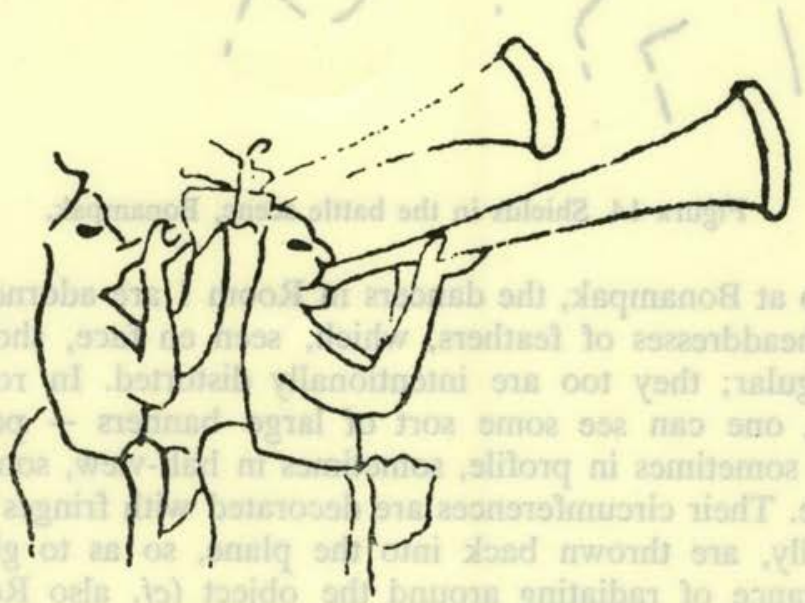

Figura 13. Musicians, Room 1, Bonampak 
throne in Room 3, there are vessels with the upper rim rounded, but in the two cases it is an error in the reproduction). Again in the battle scene at Bonampak there are, as Gendrop pointed out judiciously (1971: 104), at least two completely deformed shields because they are seen in oblique and, all things considered, in an inverted perspective; from rectangular they have become trapezoidal (fig. 14). Shields are amongst the first objects that were distorted by the Greek painters of the 6th century B.C.: round as they were, they became drawn oblong (White 1956: 22).

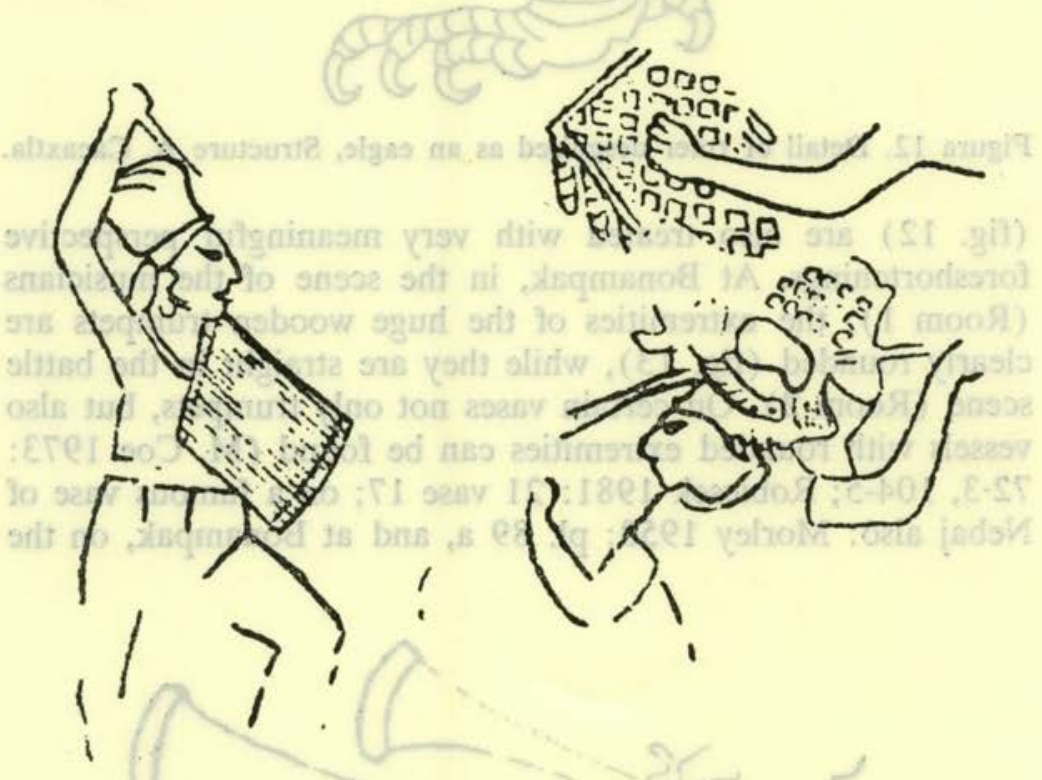

Figura 14. Shields in the battle scene, Bonampak.

Also at Bonampak, the dancers in Room 1 are adorned with huge headdresses of feathers, which, seen en face, should be rectangular; they too are intentionally distorted. In rooms 1 and 3, one can see some sort of large banners - parasols, shown sometimes in profile, sometimes in half-view, sometimes en face. Their circumferences are decorated with fringes which, normally, are thrown back into the plane, so as to give the appearance of radiating around the object (cf. also Robicsek 1981: 189 fig. $61=$ M. Coe 1981: No. 58). In the drawings 


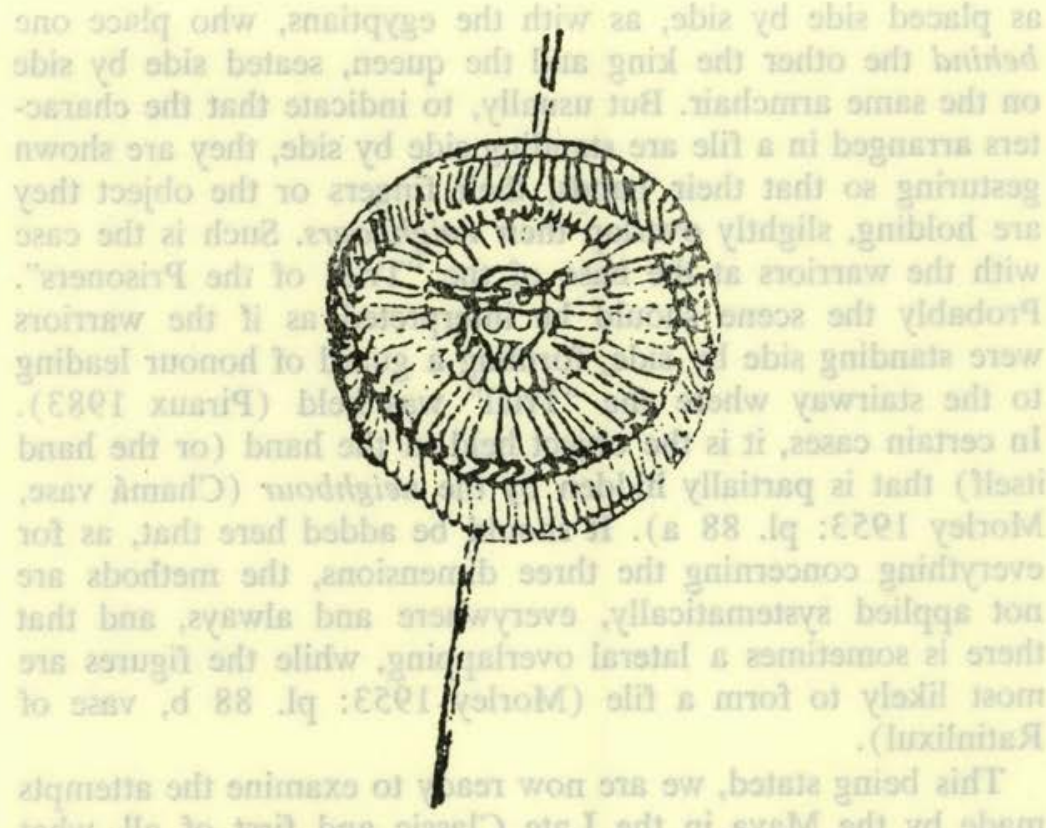

Figura 15. Fan, Room 1, Bonampak.

of Tejada, and the few pictures confirm this (Bernal 1958, pl. 18) the fringes of the banners seen en face, all hang down, so that on the sides, they shorten progressively and overlap, and become longer again towards the extremity (Piraux 1983). The impression of perspective is very clear (fig. 15).

As for the distribution of the figures in space, Grieder mentions two methods intended to suggest depth: raising the level and overlapping, one not excluding the other, as in the battle scene of Bonampak. In that scene, the overlapping is well marked; it is still clear on a vase (Robicsek 1981: 143 fig. 47) showing a throne scene, with on the foreground the warriors one behind the other, but overlapping each other slightly and in front of them, two seated characters also one behind the other and overlapping. The partial overlapping means that the warriors as well as the two other persons must be thought to stand side by side, forming two rows face to face. Sometimes the overlapping is very discreet, indeed inexistant. Even in the latter case, the figures must be imagined 
as placed side by side, as with the egyptians, who place one behind the other the king and the queen, seated side by side on the same armchair. But usually, to indicate that the characters arranged in a file are standing side by side, they are shown gesturing so that their hands, their fingers or the object they are holding, slightly overlap their neighbours. Such is the case with the warriors at the base of the "Trial of the Prisoners". Probably the scene should be interpreted as if the warriors were standing side by side, forming a guard of honour leading to the stairway where the "Trial" was held (Piraux 1983). In certain cases, it is the object held in the hand (or the hand itself) that is partially hidden by the neighbour (Chamá vase, Morley 1953: pl. 88 a). It should be added here that, as for everything concerning the three dimensions, the methods are not applied systematically, everywhere and always, and that there is sometimes a lateral overlapping, while the figures are most likely to form a file (Morley 1953: pl. 88 b, vase of Ratinlixul).

This being stated, we are now ready to examine the attempts made by the Maya in the Late Classic and first of all, what Proskouriakoff calls rightly "experiments in scenic composition", lintel 3 and stela 12 at Piedras Negras. These are two of the scenes which caused the biggest problems to the Maya and to which a number of divergent solutions were found, worthy of a special study: I mean the throne scenes. It can be said without exaggerating that their role in the development of the Mayan art during the course of the 8th century can be compared with the representation of the quadriga in the Greek art of 550 to 400 B.C. (White 1956). They are scenes where some characters call on a high dignitary, probably the ruler, who is seated on a kind of large rectangular table or cushion covered with hide. Sometimes they may be ambassadors, or lesser rulers from the neighbourhood, or vassals come to present their respects or offer gifts, sometimes prisoners brought up for trial by the ruler, one doesn't know too well. The easiest way to treat the subject is to present it in profile, as for the quadriga. But diversification was wanted, especially because the Maya became increasingly bent on showing the chief character in a scene en face. So what with the visitors who had to be kept as well as possible from masking the en- 
throned sovereign? In most cases, they were pushed to the side and they were placed one behind the other, sometimes overlapping more or less. This faulty solution had the advantage that it was possible to go on drawing the ruler's face in profile as it had to be turned towards the guests. But apparently it did not entirely satisfy the Maya, since they kept searching for something else.

D'Harcourt (1962: 100) says of lintel 3 at Piedras Negras (fig. 16) that it represents the earliest application of the laws of perspective. He barely exaggerates. On the one hand, the solution proposed by this masterpiece comes very close to the one the Copanec used to render volume: the stone is carved more deeply, but this time to create different levels. The solution is true to the tradition of Piedras Negras, where it had been a habit for a long time to place the royal characters in niches allowing to enhance their relief, and where efforts were bent towards pictural relief (e. g. base of stela 14, Morley 1953: pl. 66). So the artist hollowed out a spacious niche representing the reception room, and placed the ruler in the centre, en face, on a throne also en face, flanked on both sides with high dignitaries. The rectangular throne rests on a platform jutting out near the plane of the slab. In front of the platform, i.e. in the foreground, 7 figures are seated, those welcomed by the ruler. Although placed before the throne, they are in profile, divided into two groups facing each other from either side of the ruler; they are looking in the direction of the ruler and must be thought to turn their backs to the spectator.

Depth is thus obtained in the first place to the detriment of the support. But there is more, and two interpretations are possible here, depending on whether one wants to see more or less perspective in it. It is almost certain that the ruler is bending towards the persons he is welcoming. To render the third dimension implied by this movement, the body has been placed in diagonal, as if it were seen obliquely by an onlooker situated to the extreme right, to the left of the king. Now, the 7 visitors have been put off-axis strongly towards the left and the throne towards the right, which is logical if the whole scene has been really conceived as seen by a spectator standing to the extreme right. Moreover, an additional diagonal has been created by picturing a three-quarter back view of the first 


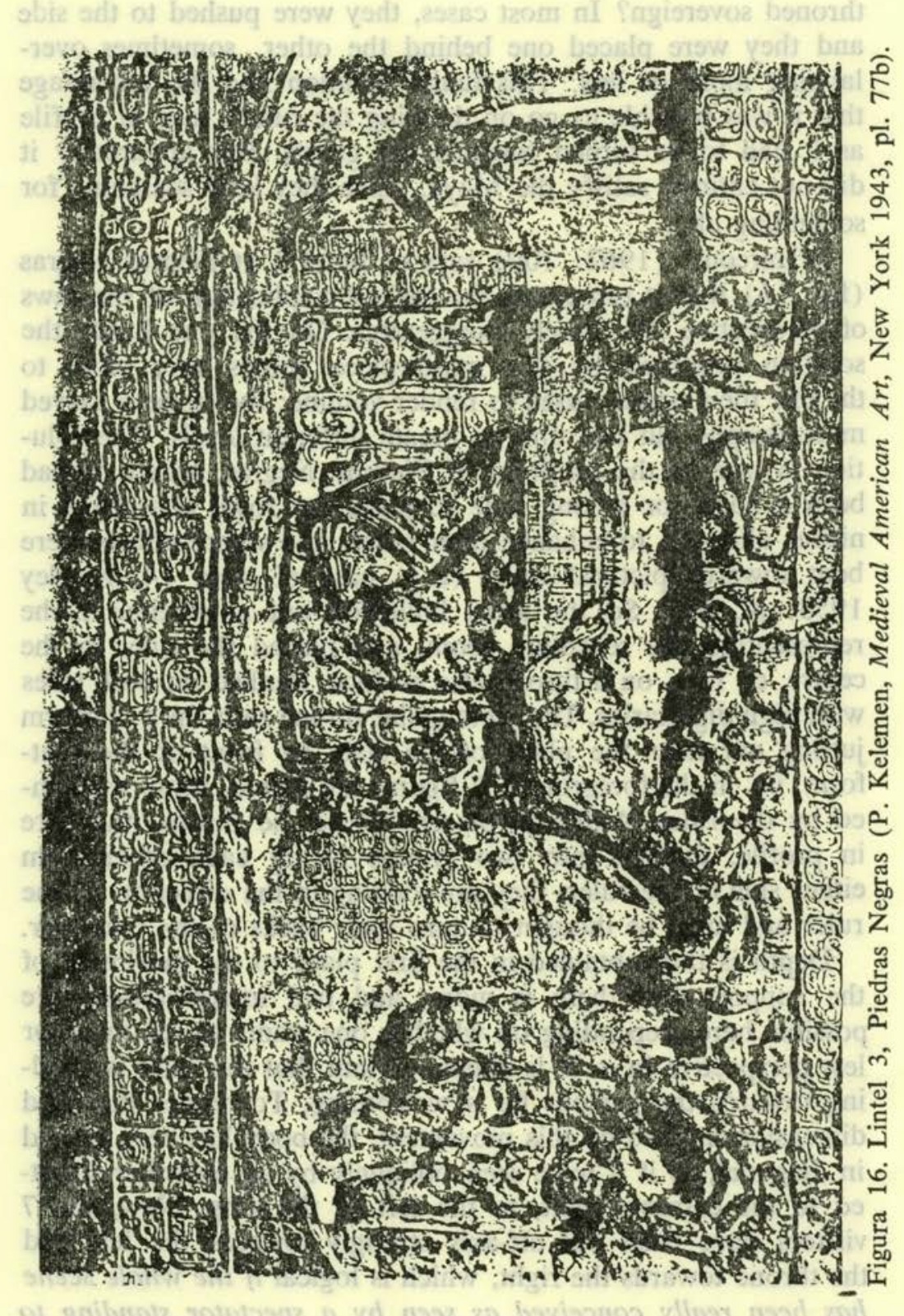


visitor to the left of the ruler and a three-quarter front view of the first dignitary to his right. Of course, to obtain a more or less correct perspective from this unique viewpoint, much more would have been needed, among other things an oblique view of the throne and of all the characters as well as some distortion of the left lateral wall. But that stage had not yet been reached. The throne is frontal, the ruler's face is in profile, just like those of the guests. It takes a genuine effort of imagination to grasp what the artist intended to do. It would, nevertheless, be absolutely remarkable that the Maya would have taken into account, for the arrangement of the guests, throne and two of the visitors, the angle from which the ruler was seen. And there are a few very beautiful oblique views of hands.

The other interpretation is simpler and more likely at first sight. Sure, the ruler is seen in oblique, but he is duly seated in the centre of the throne and his face is exactly in the axis of the composition. Consequently, his body being in diagonal, the throne had to be moved to the right and it is to compensate for this imbalance that the artist would have put the visitors off-axis to the left. One may object, however, that this second putting off-axis is excessive, while it is normal in the first interpretation.

I confess my embarrassment. Being cautious, I would be inclined to adopt the second interpretation, if it were not for the objection I just mentioned, and, above all, the other examples of attempts of perspective which will be given further on. But is it not possible also that the two interpretations are complementary to each other and that the artist took advantage of the restriction imposed on him by the oblique view of the king and the necessity to place him in the centre, to innovate? Anyhow, we have here another illustration of the importance of diagonals to suggest depth.

The scene of the throne on stela 12 (fig. 17) offers an entirely different solution which makes more allowance for the two-dimensionality of the support. The artist, nevertheless, again adopts the very efficient technique of the diagonal arrangement. To show a group of prisoners brought before the ruler en face, he resorts to echelonment and overlapping, the more rightly so, since the monument in question is a stela, that is, all in height. At the base, seated captives are arranged 


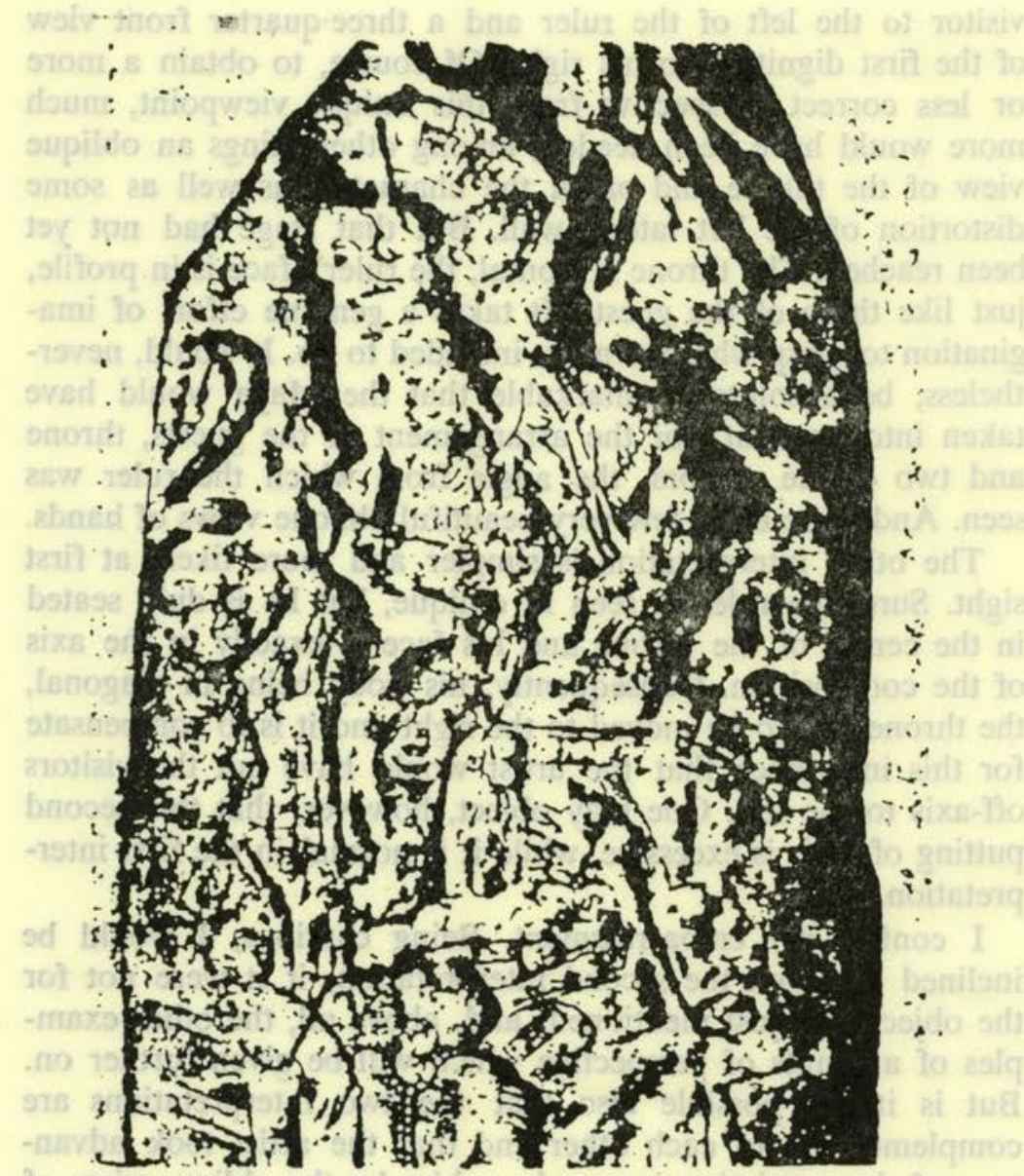

Figura 17. Stela 12, Piedras Negras (Robicsek 1975, p. 180).

in tiers and overlapping each other. The most important captive is placed in the middle. He has his head turned up towards the ruler and he is flanked by two warriors in arms, standing and in profile. At the top and, consequently, the farthest from the onlooker, the ruler is negligently seated on his throne: he is en face, shoulders slightly in a three-quarter angle. His relief is more sharply marked, since, placed as he is on top of a high stela, the chances were that otherwise he would be less visible than the other characters of inferior rank. Clearly the standpoint of the onlooker is taken into account. 
The ruler's face in profile is turned down: he is actually looking down upon the prisoners and his forward movement is rendered, as on lintel 3 , by placing his shortened torso slightly in oblique, as if he were seen from the right. The top of the pyramid formed by the captives arranged in tiers, is decentred to the left, as was the case for the visitors on lintel 3; on the one hand because the principal prisoner must be face to face with the ruler, on the other maybe, because the spectator's standpoint is to the right.

So these are two original ways to represent a throne scene which have in common the wish to get the effect of space, either by hollowing out the stone and thus creating real depth, or by arranging in tiers thereby coming close to a bird's eye view. In both cases the ruler is placed in diagonal to suggest that he is leaning forwards. Let us keep in mind that at Bonampak, the diagonal of the Trial of the Prisoners represents a figure lying backwards. On a codex style vase already mentioned (fig. 6), the oblique position of a recumbent person also gives him a certain depth in space. This depth is suggested by another means: the man is in fact surrounded by concentric ovals. Considering the context - a mythical hunting scene in the midst of nature, it is very plausible that the egg-shaped rings represent circles of water around the figure lying in a pool and that those circles are distorted for reasons of perspective.

But let us return to the throne scenes and to an entirely novel experimentation by an artist of Yaxchilán, in which, by distorting an object in the same way as the shields at Bonampak or the above-mentioned water circles, an attempt is made to create real three-dimensional space, a rudimentary perspective. The panel at the Metropolitan Museum of Art (fig. 18) presents a ruler en face, whose face in profile is turned towards two dignitaries handing him insignia. The problem remains the same: how to make it understood that those dignitaries are before and not beside the throne?

The visitors are one behind the other but the hand of the second to the left overlaps the skirt of his companion. They consequently should be imagined one beside the other and, more precisely, seen in oblique by a spectator finding himself more or less in the middle, judging by the fact that the right leg of the 


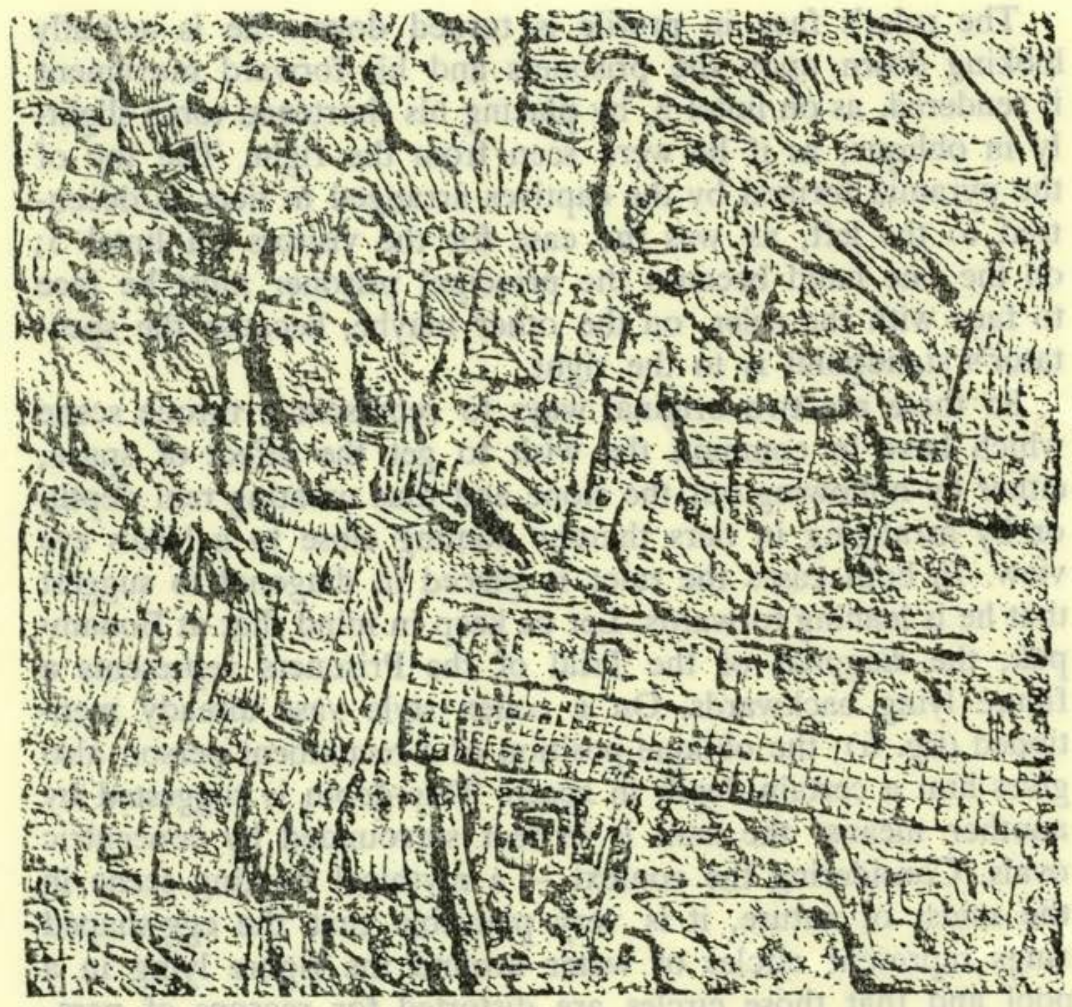

Figura 18. Lintel of La Pasadita (The Metropolitan Museum of Art, The Michael C. Rockefeller Memorial Collection, Bequest of Nelson A. Rockefeller, 1979).

second is rather far in recess compared to the other. As for the ruler's throne, it is truly aberrant: seen apparently en face, it slopes considerably to the left so that its left leg is notably shorter than the other. Simpson (1976: 97) says about it that it has a "curious sloping effect" while Greene (1972: 140) finds it sufficient to underline its "unusual" character. Are we confronted with a gross error of the artist? However, the quality of the relief is excellent in many ways. Was the throne really inclined laterally? It would have been most uncomfortable. The only valid explanation must be found in the light of everything mentioned up to now: what we have here is an oblique view of the throne, which has to be imagined facing both digni- 
taries. The ruler himself is also seen in oblique from the centre, first because he touches upon an inclined surface, second because his right shoulder, the furthest from the onlooker, is shortened and lower than the other. And finally because the pectoral is moved to the left rather clumsily to tell the truth.

Note that the right leg of the throne should have been shorter; as it has been prolonged to the edge, this can only be because of the principle of "attraction of the terrestrial line".

The ruler being poorly portrayed in three-quarter on an oblique throne seen from above, since the farthest side is the highest, one must imagine a vanishing line departing from the right, going to the centre, while the arrangement of the visitors is to suggest a second vanishing line (or rather a plane) crossing the first one. Here, we approximate what is usually understood by a "perspective".

The relief originates somewhere near Yaxchilán, probably from a minor site. It may be that in the sizeable communities it was not so easy to get away with such liberties with the hieratic image of an enthroned king. It must be added that the sides of the throne are not shown. Similar cases occur in Chinese Art at the dawn of perspective. I am thinking in particular of a stela of the seated Buddha Maitreya, of A.D. 471, the reverse side of the stela decorated with reliefs showing several scenes of the life of the Buddha. One of those scenes shows the Maitreya in the moon, preparing to penetrate into the body of his mother, sleeping inside a house represented beside the lunar disc (fig. 19). To make it quite clear that the Maitreya has to penetrate into the house, that therefore

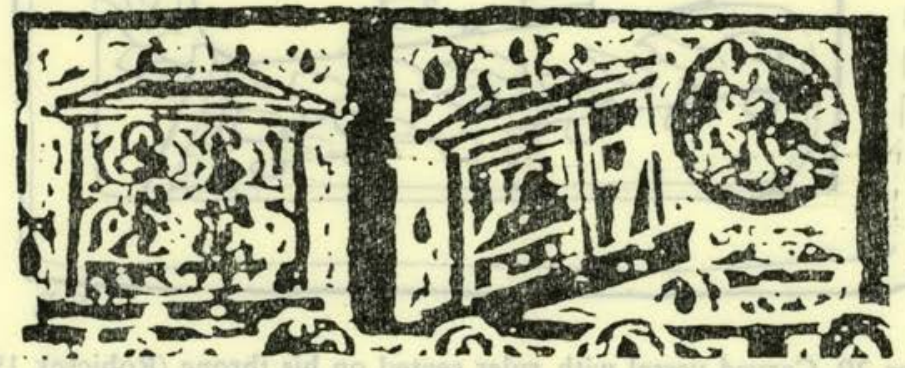

Figura 19. Stela of Buddha Maitreya, detail. 
he finds himself before the façade and not beside it, the artist has distorted the house, which from rectangular has become a parallelogram (Trésors d'art de la Chine 1982: 169 fig. 136). Here, the sides of the distorted object are not shown either.

The throne from somewhere near Yaxchilán is not an isolated case. A vase of the Museum of the American Indian, again published by Robicsek, shows a similar scene. (fig. 20).

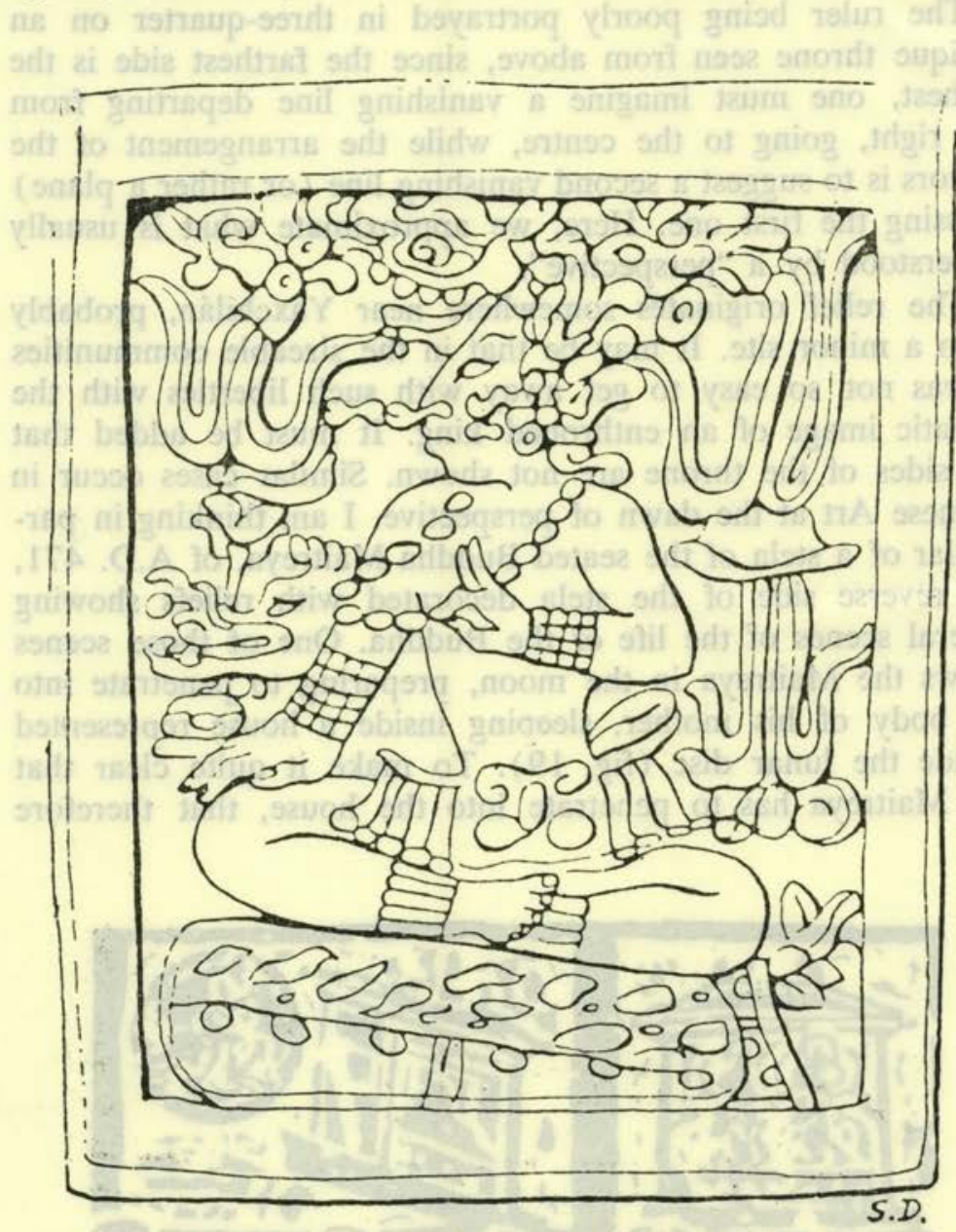

Figura 20. Carved vessel with ruler seated on his throne (Robicsek 1975, fig. 78). 
A ruler is represented sitting on his throne, looking to the right. The body is presented from a three-quarter angle, as indicated principally by the pectoral turned to the same side as the face and the fact that the doubled-up inferior limbs are arranged in oblique. So there is an obvious determination to suggest depth. In this case also, the throne, a bulky cushion covered with a jaguar skin is distorted so as to show an inclination similar to that of the throne described before. Sure, such distortions of cushions are often shown on painted vases and they are mostly the result of the cursive style of the artist (Robicsek 1978: 186 fig. 208 f.i.). But they are always scenes where the ruler is represented in profile and not in threequarter. Moreover, the scene of the Museum of the American Indian is not painted, but in relief, and therefore the explanation of the cursive style does not hold. Hence the distortion of the throne is explicable only because of the oblique view, as in the case of the Metropolitan relief.

There is another very interesting example of an attempt to create a void space by distorting a design which, in a nonperspective art, should be rectangular (fig. 21). On a vase with an aberrant throne scene, a man is kneeling in front of a room housing a jaguar-shaped throne supporting the head of the Mexican deity Tlaloc. The jaguar-throne stands on what seems to be at first glance, a platform supporting a dais with curtains. But the platform has a trapezoidal shape, although there is no such thing either in the art, or in the architecture of the Maya. What is more, the legs of the feline do not rest on the upper line of this trapezoidal shape, but are put right in the middle. Consequently, it seems that what we have here is a surface seen in perspective, made trapezoidal and not a platform seen in elevation, not even if the vertical column supporting the dais, stands itself on the upper line of the trapezium. There remains the possibility of an error by the artist, but errors of this kind may well have paved the way to perspective. On the other hand, a distortion not unlike this one, occurs on a Greek vase 425 B.C. published by Richter (n.d. fig. 157).

Now that the Maya determination to suggest both space and depth on flat surfaces seems very clear, it may be interesting to carefully examine one of the major scenes of the Bonampak 


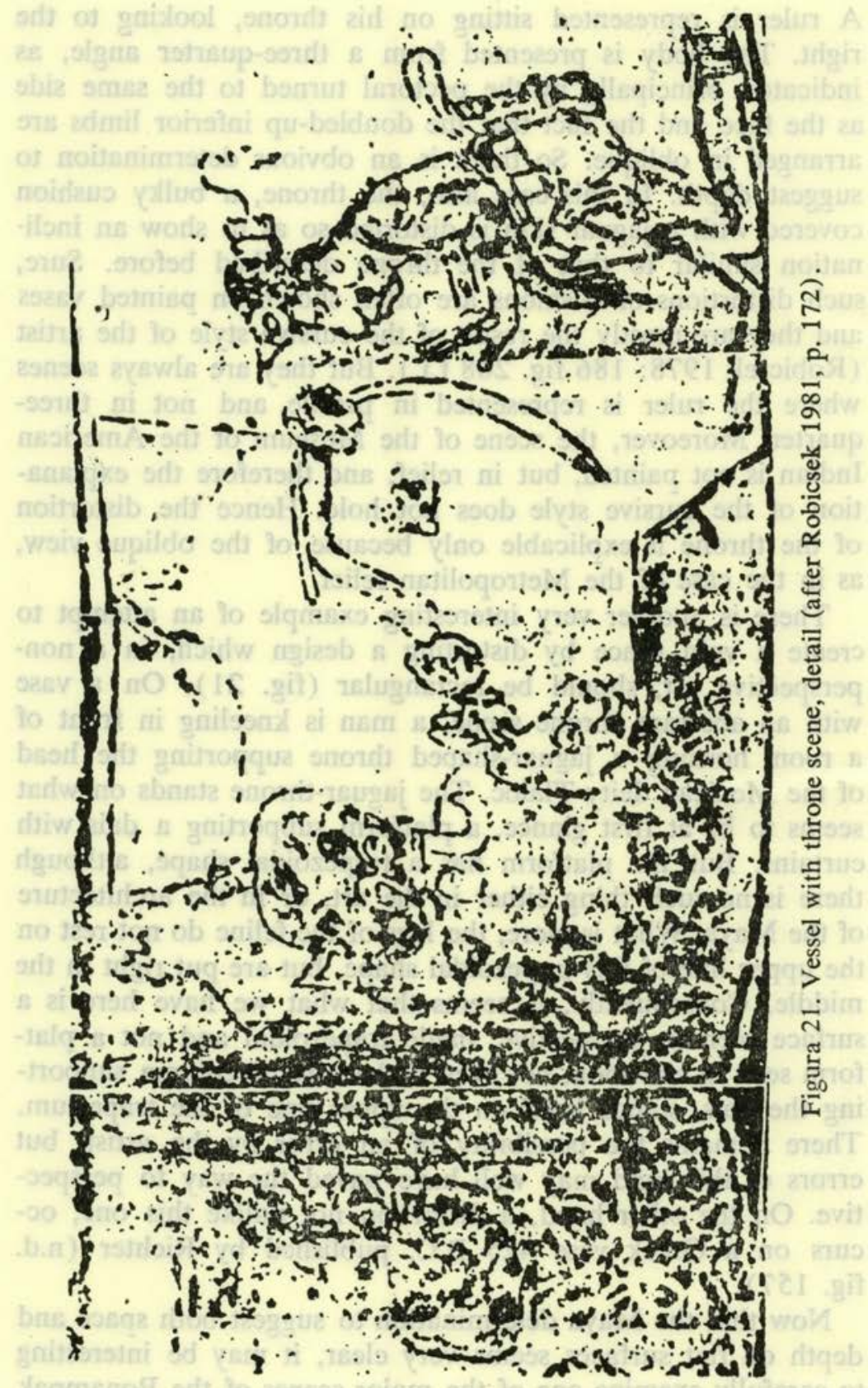




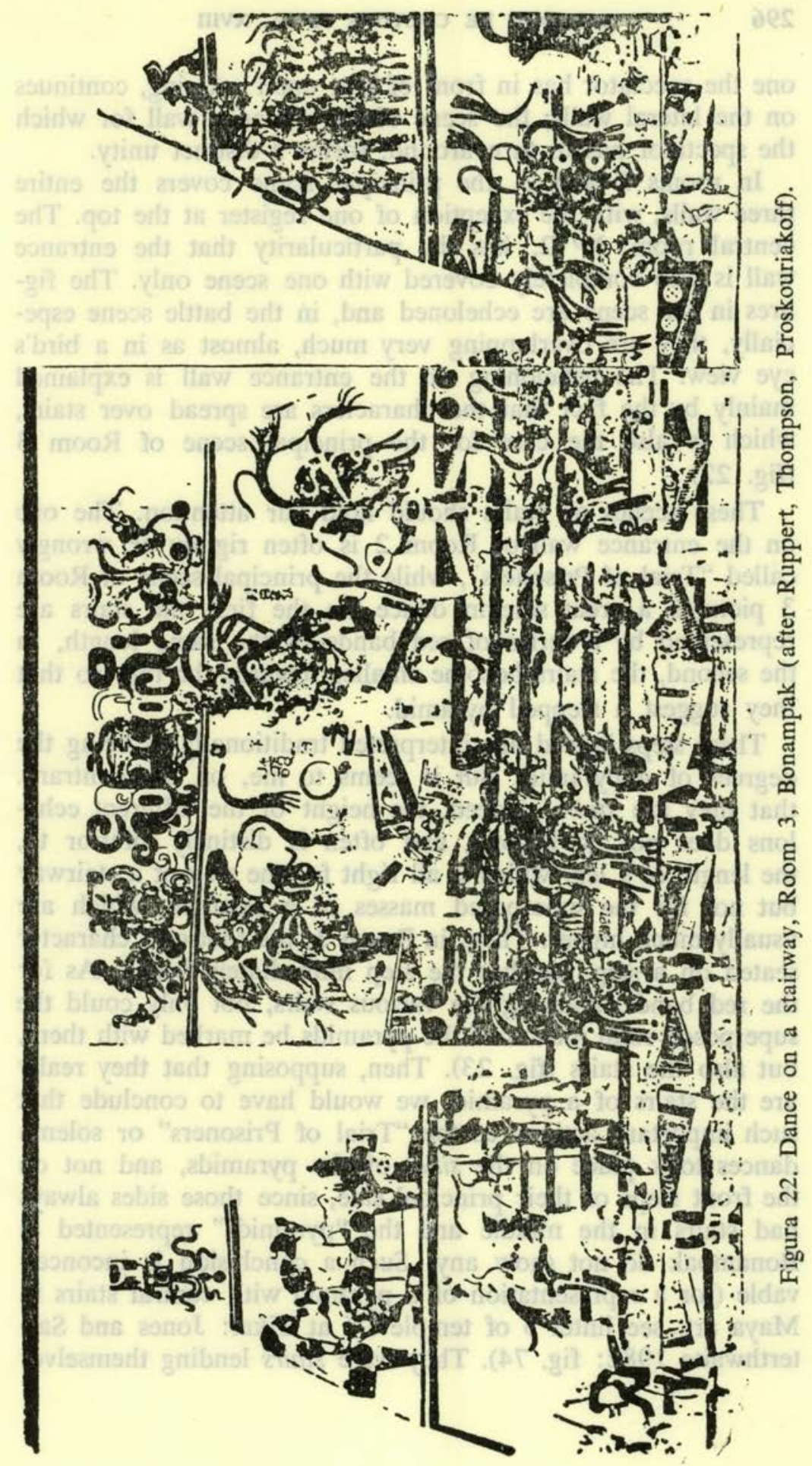

Estudios de Cultura Maya. Vol. XVIII, 1991

Instituto de Investigaciones Filológicas/

Centro de Estudios Mayas, UNAM

ISSN 0185-2574 
one the spectator has in front of him upon entering, continues on the lateral walls; the scene of the entrance wall for which the spectator has to turn around, forms a distinct unity.

In rooms 2 and 3 , the principal scene covers the entire three walls, with the exception of one register at the top. The central room, $\mathrm{N}^{\circ} 2$, has the particularity that the entrance wall is also completely covered with one scene only. The figures in the scene are echeloned and, in the battle scene especially, they are overlapping very much, almost as in a bird's eye view. The echeloning on the entrance wall is explained mainly by the fact that the characters are spread over stairs, which is also the case for the principal scene of Room 3 (fig. 22).

These scenes on stairs should hold our attention. The one on the entrance wall of Room 2 is often rightly or wrongly called "Trial of Prisoners", while the principal scene of Room 3 pictures a great solemn dance. In the first, the stairs are represented by a series of red bands of the same length, in the second, the stairs become smaller towards the top, so that they suggest a stepped pyramid.

These steps indeed are interpreted traditionally as being the degrees of a pyramid. But it seems to me, on the contrary, that they are stairs: indeed, the height of the different echelons does not go beyond, and often is distincly inferior to, the length of a leg, which is all right for the step of a stairway but not for the superposed masses of a pyramid, which are usually much higher. Then, in Room 3, the foot of a character seated on a step, touches the step immediately below. As for the red bands, marking the various stairs, not only could the superposed solid masses of the pyramids be marked with them, but also the stairs (fig. 23). Then, supposing that they really are the stairs of a pyramid, we would have to conclude that such important actions as the "Trial of Prisoners" or solemn dances took place on the sides of the pyramids, and not on the front steps of their principal side, since those sides always had stairs in the middle and the "pyramids" represented at Bonampak do not show any, Such a conclusion is inconceivable (for a representation of a pyramid with central stairs in Maya art, see lintel 3 of temple IV at Tikal: Jones and Satterthwaite 1982: fig. 74). They were stairs lending themselves 


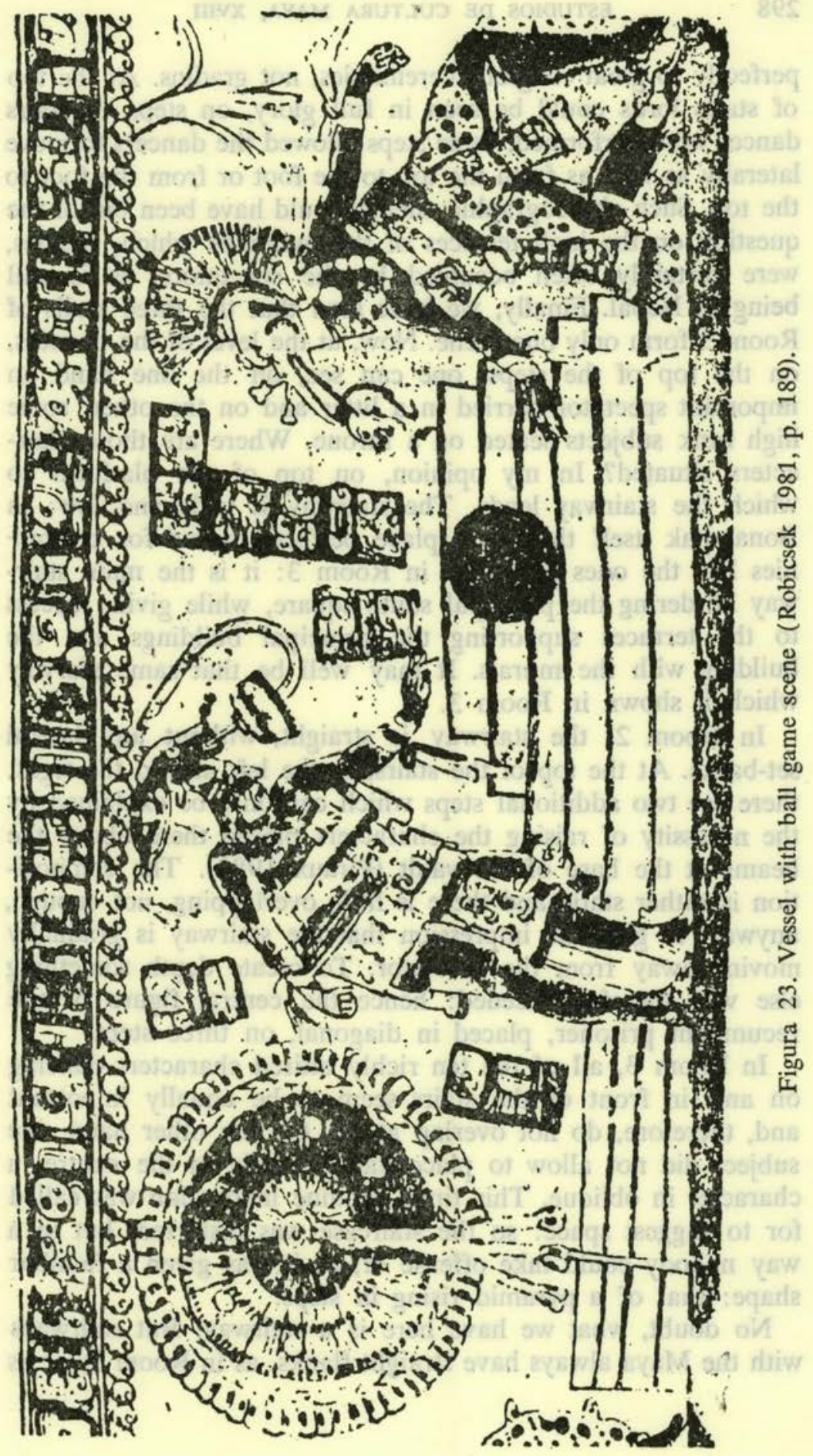


perfectly to great religious ceremonies, not gradins. At the top of stairs lords could be seen in full glory, on steps of stairs dances were performed, these steps allowed the dancers to move laterally as well as from the top to the foot or from the foot to the top. Such choreographic effects would have been out of the question on the high terraces of the pyramids which, besides, were certainly often occupied by the spectators, as is still being in Nepal. Finally, we have seen that the three walls of Room 3 form only one scene. Now, at the level of the dancers, on the top of the steps, one can see, on the one hand an important spectator carried in a litter and on the other, some high rank subjects seated on a throne. Where are those characters situated? In my opinion, on top of the platform to which the stairway leads. The stairway is wide and low; in Bonampak itself there is a place perfectly suited for ceremonies like the ones presented in Room 3: it is the main stairway bordering the principal south square, while giving access to the terraces supporting the principal buildings and the building with the murals. It may well be that same starway which is shown in Room 3.

In Room 2, the stairway is straight, without any lateral set-backs. At the top of the stairs, to the left and to the right, there are two additional steps which can only be explained by the necessity of raising the characters placed there above the beams at the base of the vault (Piraux 1983). The composition is rather static and there is little overlapping, not enough, anyway, to give the impression that the stairway is gradually moving away from the spectator. To create depth something else was therefore needed: hence the central figure of the recumbant prisoner, placed in diagonal, on three steps.

In Room 3, all of the ten richly attired characters dancing on and in front of the stairs seem to be equally important and, therefore, do not overlap at all. On the other hand, the subject did not allow to place harmoniously in the centre, a character in oblique. This time, genuine innovation was called for to suggest space: so the staircase was distorted, but in a way nobody could take offense of, as it was given a familiar shape: that of a pyramid rising in steps.

No doubt, what we have here is a stairway. But stairways with the Maya always have straight flanks, as in Room 2, or as 
on a Maya vase already mentioned (fig. 23 , to the left). To put it in another way, they practically never have lateral setbacks from one step to another, except when the steps go all the way round the building, as on the ball game court at Copan. In the Bonampak region and in Bonampak itself anyhow, the sides of the stairways are always straight. Hence, if the stairway of Room 3 narrows towards the top, it can only be for reasons of perspective, because the top is further away from the spectators than the base. Narrowing it gives an impression of depth; it provides the diagonals that could not be introduced otherwise. Turning the stairway into a trapezium also allowed to present more dancers at the base (7) than at the top (3), (or, taking only the wall in the back, 4 at the base) which enhances the impression of narrowing towards the top and mutiplies the obliques.

The effect of depth is of course considerably softened by the fact that the set-backs extend to the lateral walls of the rooms. It is only perceptible when moving the eyes towards the corners of the room. But there is every indication that the artist has prepared his plan on a flat surface. In any case, he did not very much take into account the constraints exerted by the structure of the building he was to decorate.

One might object that the set-backs are the effect of a combination of front and side-face views as can sometimes be found in the Mexican codices. In these codices the method of representation is definitely "pre-Greek". However, the combination of front and side-face can only be found on one side of a stairway, never on both sides, for the good reason that it is not necessary to represent the same profile twice (fig. 24). Next, it is on the left wall of Room 3 at Bonampak, to the left of the stairway which might be "in profile" that the character sitting on a step is shown; now, he is sitting on the step itself, not on the side with the set-backs. Finally, even if, after all, we should be in the presence of a combination of front and side-face views, it is certain that here it was used to give depth to the scene.

The Maya would probably have represented the stairway of Room 2 also in "perspective" if the subject and the length of the wall had allowed them to do so. They did not do so and the fact could not offend them, since the image actually 


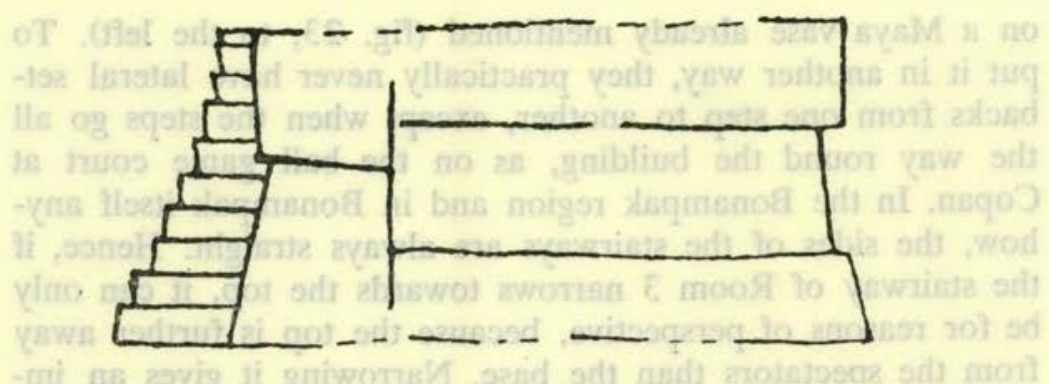

Figura 24. Pyramidal structure with stairway, Codex Nuttall, p. 8.

corresponds to a stairway with flancs seen en face. But, should they have wanted to represent a pyramid, it is doubtful that they would have allowed themselves to cut set-backs essential to the represented structure.

So at Bonampak, too, also the diagonals are there to create depth. We have seen that the arrangement of the dancers also created oblique lines towards the top, that is, towards the back. The composition in diagonal occurs in ceramics. On a well known vase from a tomb under Temple I at Tikal (W. Coe 1967: 102; Foncerrada de Molina and Lombardo de Ruiz 1979: 232-3), the ruler is sitting on a throne, on a platform composed of two tiers one set back from the other. The throne and the tiers introduce into the composition a diagonal which is enhanced by the fact that the first "visitor" of the ruler is half-kneeling at the top of the platform, while the second has one foot on the platform and the other on the first step, and that the others, finally, are on the ground level. If the mappings are accurate, we must admit that the upper angles of the throne and the steps are almost perfectly alined, while the extremities of the left foot of the ruler, the left knee of the first visitor, the foot of the second visitor, and the left foot of the third and fourth visitors are placed exactly in a similar oblique, thus ruling out the hazard factor for the diagonal. The vase of Tikal has another peculiarity: to enhance the effect of depth, the artist has not hesitated to partially mask the throne with kneeling characters in profile, but which should be imagined with their backs to the spectator and facing 
the ruler. It should be pointed out that it is a cylindrical vase and that the diagonal arrangement has as little effect as the set-backs of the stairway on the lateral walls at Bonampak: for such vases, with such a carefully studied arrangement, it is likely that a draft was made first (see also Robicsek 1981; 143 fig. 47a).

The ancient Greeks turned to echelonment to represent the individuals most distant in space. Only very late in time did they decide to make them smaller. Maybe the Maya also ventured to attempt reducing the more distant characters. Taylor (1978: 85) publishes a vase on which two superposed rows of characters face an anthropozoomorphic being. Now, the subjects of the top row -that is, the more remote- are systematically a bit smaller than the others. An explanation on the grounds of the hierarchical importance of the figures cannot be retained, as the upper characters are obviously doublets of the ones in the first row. Other examples of reduction of figures occur (e.g. Robicsek 1981: 143 fig. 47a) and the matter deserves to be looked into.

In conclusion, I am convinced that in Late Classic times the Maya multiplied the experiences in a number of ways to render the third dimension in relief and painting. They seem to have developed a wide range of more or less complex techniques. Should detailed studies of the various points touched upon in the article confirm that point of view, force would be to admit that they were on the treshold of perspective. Because the Greeks put to work the same techniques towards the end of the 6th century and these led them to the discovery of perspective. To that time date back the oblique views of characters, the distortion of objects, the step by step, non systematic foreshortenings. It is only towards 475 B.C. that the Greeks managed to make convincing bodies in three-quarter; thereafter, things developed extremely fast.

Maya art would, therefore, no longer be entirely "preGreek" in the way Schäfer thought, and the Greeks would thus not be the only ones to have entered independently upon the way to three-dimensionality. As far as we know, it is as yet impossible to prove that Mesoamerica has been subject to Old World influences whatsoever. It is certainly not by chance 
that investigations into three-dimensionality developed in the most elaborate pre-colombian civilization and at its peak.

If the Maya civilization had not collapsed suddenly, would they have gone as far as the Greeks? That is of course impossible to tell, although one can doubt it, because in Greece perspective is just one - significant- factor of the "Greek miracle". Here for the first time in the history of mankind we witness the fundamental passage from mythical, analytical, associationist, disuniting, anthropocentric or "pre-copernician" thought (Douglas 1971: 98-110, with man viewing himself as the center of a universe peopled with wills directed at him) to methodical, scientifical, philosophical, synthetical, unifying, critical, relativistic thought. Instead of imagining more or less personified causes everywhere, man endeavors to reduce the causes. For the first time a society tries and sees itself and its religion and gods from the outside, putting things in a true perspective, accepting the fact that things change according to the viewpoint; and, of course, this attitude is nowhere more obvious that in art. One passes from an analytical, juxtaposing, multiplying, often repetitive, and anthropocentric art, in which every single element has to present itself frontally to the spectator, to a synthetical art with well integrated figures and viewpoints as reduced as possible. When after 1500 years of mythical-religious thought, modern thought rises for the second time, during the Renaissance, then simultaneously perspective reappears also.

Maya thought certainly still was essentialy mythical-simbolical, but is true perspective therefore really inconceivable? It is also difficult to imagine why, if there had not been a waning, the Maya would have suddenly interrupted their investigations into three-dimensionality and how their open, non-integrated art, full of promises, could have frozen. Obviously further research is needed, as well on Maya art as on the birth and development of perspective in other places (where, and how many times independently?) and on their circumstances, for the problem is of fundamental importance. 


\section{BIBLIOGRAPHY}

Anton, Ferdinand

1970 Art of the Maya, London.

BAINES, JoHN, see SCHAEFER 1974

BEFORE CORTÉS

1970 Sculpture from Middle America, A Centennial Exhibition at the Metropolitan Museum of Art. (Catalogue by Elizabeth Kennedy Easby and John F. Scott), The Metropolitan Museum of Art, New York.

BERNAL, IGNACIO

1958 Mexique, peintures pré-hispaniques. UNESCO, New York.

Brunner-Traut, Emma, see Schaefer 1974

Coe, Michael D.

1973 The Maya Scribe and his World. Grolier Club, New York.

1978 Lords of the Underworld, Masterpieces of Classic Maya Ceramics. Princeton Univ. Press. Princeton.

1982 Old Gods and Young Heroes, The Pearlman Collection of Maya Ceramics. Photographs by Justin Kerr (exhibition catalogue), The Israel Museum, Jerusalem.

Coe, William R.

1967 A Handbook of the Ancient Maya Ruins. Univ. Museum, Univ. of Pennsylvania, Philadelphia.

d'Harcourt, Raoul

1962 Pre-Columbian Civilization. In Art and Mankind, Larousse Encyclopaedia of Prehistoric and Ancient Art: 98-103, London.

Donnan, Christopher B.

1976 Moche Art and Iconography. UCLA, Los Angeles.

Foncerrada de Molina, Marta and Sonia Lombardo de Ruiz

1979 Vasijas pintadas mayas en contexto arqueológico (Catálogo). UNAM, México City.

GendRop, Paul

1971 Murales prehispánicos. Artes de México 144, Mexico City.

GiosefFi, DeCio

1966 "Perspective". In Encyclopaedia of World Art. 11: 183-221, London. 
Graulich, Michèle and Michel

n.d. Sculptures de la Côte du Golfe, de l'aire maya et de l'Oaxaca aux Musées Royaux d'Art et d'Histoire de Bruxelles. Corpus Antiquitatum Americanensium, Brussels (in press).

Greene, Merle (ed.)

1972 Maya Sculpture from the Southern Lowlands, the Highlands and the Pacific Piedmont, Guatemala, Mexico, Honduras, Berkeley, Calif.

GRIEDER, TERENCE

1964 Representation of Space and Form in Maya Painting

IVERSEN, ERIK on Pottery, In American Antiquity 29, 4: 442-48.

1975 Canon and Proportions in Egyptian Art. Warminster, England.

Jones, Christopher and Linton Satterthwatte

1982 The Monuments and Inscriptions of Tikal: The Carved Monuments. Tikal Reports 33A, The Univ. Museum, Univ. of Pennsylvania.

Kubler, George A.

1975 The Art and Architecture of Ancient America, The Mexican, Maya and Andean Peoples, Harmondsworth.

León-Portilla, Miguel

1968 Los antiguos mexicanos a través de sus crónicas y cantares, Mexico City.

Morley, Sylvanus G.

1953 La civilización maya, Mexico City.

Piraux, MarianNe

1983 Les peintures murales de Bonampak. (Mémoire de licence, Université Libre de Bruxelles), 2 vols., Brussels (ms).

Principes d'analyse scientifique.

1978 La sculpture, méthode et vocabulaire. Imprimerie nationale, Paris.

ProskouriakofF, Tatiana

1950 A Study of Classic Maya Sculpture. Carnegie InstituQuirarte, JACINTO tion Washington, Publ. 593, Washington, D.C.

1978 "The Representation of Place, Location, and Direction on a Classic Maya Vase". In Tercera Mesa Redonda de Palenque 4: 99-110, Pre-Columbian Art Research Cen- 
ter, Palenque, Chiapas, Mexico City and Monterey, Calif.

Richter, Gisela M. A.

n.d. Perspective in Greek and Roman Art. London, New York.

ROBICSEK, FRANCIS

1975 A Study in Maya Art History: The Mat Symbol. The Museum of the American Indian, Heye Foundation, New York.

1978 The Smoking Gods, Tobacco in Maya Art, History, and Religion. Univ. of Oklahoma Press, Norman.

1981 The Maya Book of the Dead, The Ceramic Codex. Univ. of Virginia Art Museum, Charlottesville.

Ruppert K., ERIC S. Thompson and Tatiana Proskouriakoff,

1955 Bonampak, Chiapas, Mexico, Carnegie Institute Washington, Publ. 602, Washington, D.C., 1955.

SCHAEFER, HEIRICH

1919 Von Ägyptischer Kunst, besonders der Zeichenkunst. 2 vols., Leipzig.

1974 Principles of Egyptian Art. Edited by Emma BrunnerTraut, translated and edited by John Baines, with a Foreword by E. H. Gombrich, Oxford Univ. Press.

SELER, EduARD

1902-23 Gesammelte Abhandlungen zur Amerikanischen Sprach- und Altertumskunde. 5 vols., Berlin.

SiMPSON, JON ERIK

1976 "The New York Relief Panel and some Associations with Reliefs at Palenque and elsewhere", Part I. In The Art, Iconography and Dynastic History of Palenque, Part III, Pre-Columbian Art Research, the Robert Louis Stevenson School, Pebble Beach, Calif.: 95-105.

SOUSTELLE, JACQUES

1966 L'art du Mexique Ancien, Paris.

TAte, Carolyn

1983 Review of "Old Gods and Young Heroes". In African Arts 16, 2: 86-8.

TAYLOR, DICEY

1978 "The Cauac Monster". In Tercera Mesa Redonda de Palenque IV, Pre-Columbian Art Research Center, Palenque, Chiapas, Mexico and Monterey, Calif.

Trésors d'art de la Chine.

1982 (Exhibition catalogue, Brussels, Palais des BeauxArts), Brussels. 


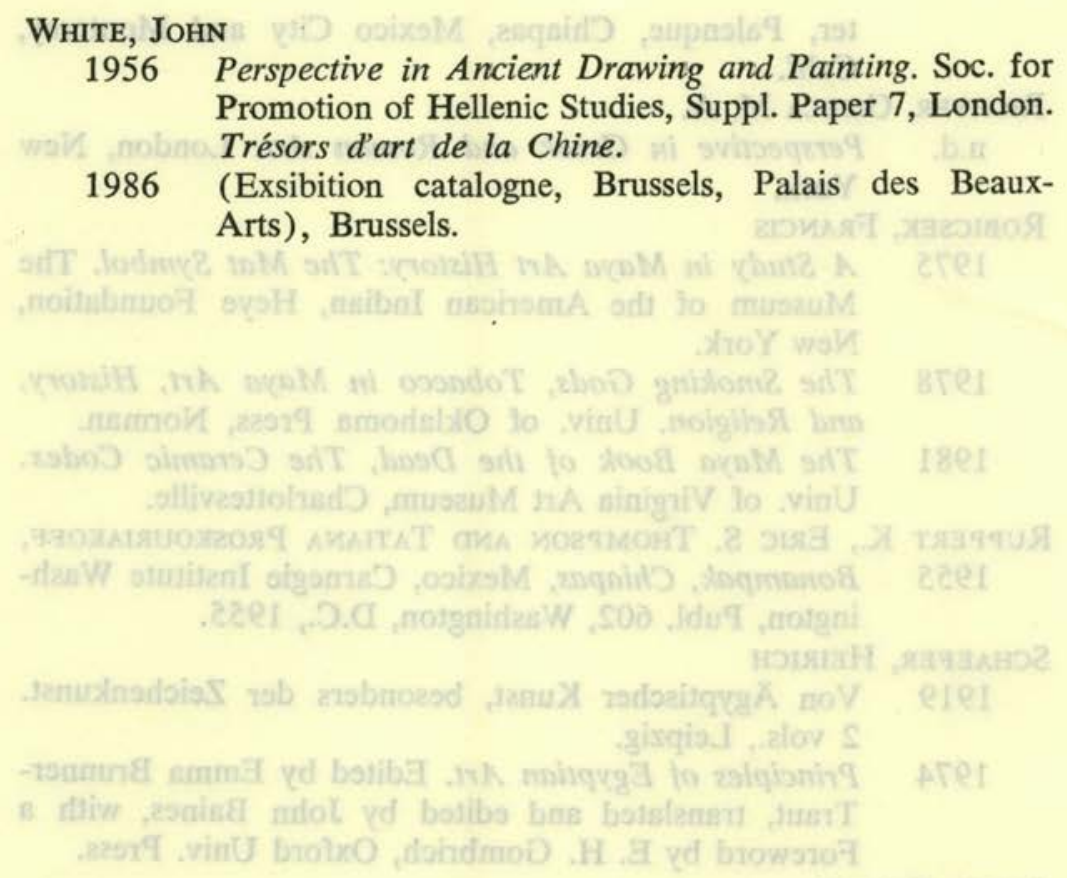

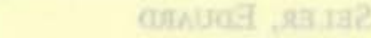

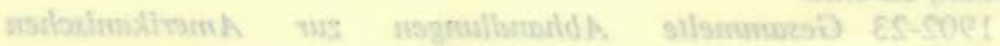

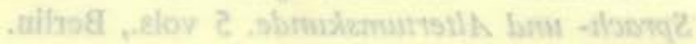

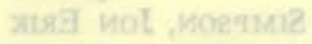

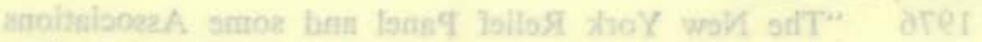

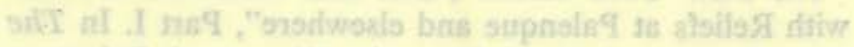

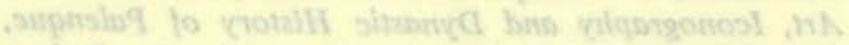

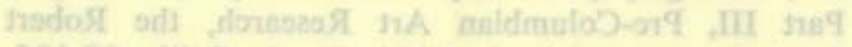

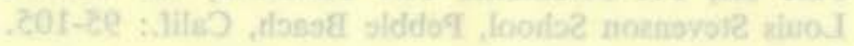

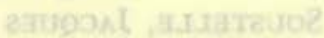

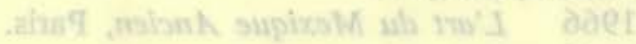

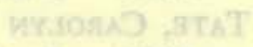

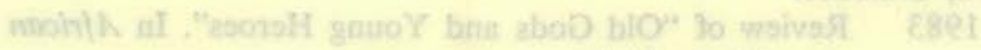
$.8-78: S, 01$ myk

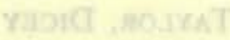

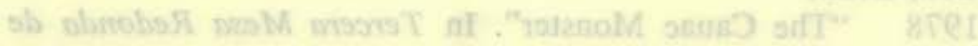

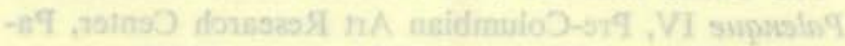

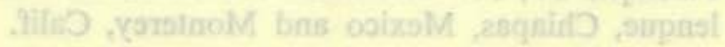

sation wh she trath eronent?

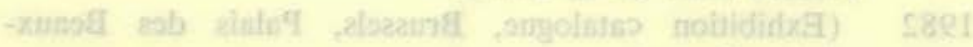

